\title{
The role of the Amazon Basin moisture in the atmospheric branch of the hydrological cycle: a Lagrangian analysis
}

\author{
A. Drumond ${ }^{1, *}$, J. Marengo ${ }^{2}$, T. Ambrizzi ${ }^{3}$, R. Nieto ${ }^{1}$, L. Moreira ${ }^{4}$, and L. Gimeno ${ }^{1}$ \\ ${ }^{1}$ Ephyslab, Facultad de Ciencias, UVIGO, Ourense, Spain \\ ${ }^{2}$ CCST INPE, Cachoeira Paulista, Sao Paulo, Brazil \\ ${ }^{3}$ Instituto de Astronomia, Geofisica e Ciencias Atmosfericas, USP, Sao Paulo, Brazil \\ ${ }^{4}$ Institute of Applied Physics, University of Bern, Bern, Switzerland \\ Correspondence to: A. Drumond (anitadru@uvigo.es)
}

Received: 20 December 2013 - Published in Hydrol. Earth Syst. Sci. Discuss.: 22 January 2014

Revised: 23 May 2014 - Accepted: 1 June 2014 - Published: 11 July 2014

\begin{abstract}
We used a Lagrangian model (FLEXPART) together with the 1979-2012 ERA-Interim reanalysis data to investigate the role of the moisture in the Amazon Basin in the regional hydrological budget over the course of the year. FLEXPART computes budgets of evaporation minus precipitation by calculating changes in the specific humidity along forward and backward trajectories. The tropical Atlantic is the most important remote moisture source for the Amazon Basin. The tropical North Atlantic (NA) mainly contributed during the austral summer, while the contribution of the tropical South Atlantic (SA) prevailed for the remainder of the year. At the same time, the moisture contribution from the Amazon Basin itself is mainly for moisture supplying the southeastern South America. The 33-year temporal domain allowed the investigation of some aspects of the interannual variability of the moisture transport over the basin, such as the role of the El Niño Southern Oscillation (ENSO) and the Atlantic Meridional Mode (AMM) on the hydrological budget. During the peak of the Amazonian rainy season (from February to May, FMAM) the AMM is associated more with the interannual variations in the contribution from the tropical Atlantic sources, while the transport from the basin towards the subtropics responds more to the ENSO variability. The moisture contribution prevailed from the SA (NA) region in the years dominated by El Niño/positive AMM (La Niña/negative AMM) conditions. The transport from the Amazon towards the subtropics increased (reduced) during El Niño (La Niña) years.
\end{abstract}

\section{Introduction}

The Amazon Basin contains a great variety of ecosystems, including the largest tropical forest on the planet. Precipitation is approximately $2300 \mathrm{~mm}_{\text {year }}^{-1}$ and the discharge of the Amazon River into the Atlantic Ocean corresponds to $18 \%$ of the total discharge of freshwater into the oceans. This river drains an area of $6.2 \times 10^{6} \mathrm{~km}^{2}$ and discharges an average of $6300 \mathrm{~km}^{3}$ of water to the Atlantic Ocean annually (Marengo and Nobre, 2009). It is known that the Amazon rainforest plays an important role in the global energy and hydrological budgets, and has been suffering for some time from intense deforestation. Unfortunately, the temporal and spatial data coverage is poor over the basin, and most studies are based on numerical products (reanalysis projects) and observational data over just a few points for a short period of time.

The climatological annual cycle of precipitation is not homogeneous over the Amazon, and the start and end of the rainy season vary gradually from the southern basin northwards (e.g. Marengo et al., 2001; Liebmann and Marengo, 2001; Carvalho et al., 2011). In the southern part of the basin, the rainy season occurs between austral spring and autumn, while over the western and the northern Amazon it extends from austral autumn to spring.

The role of Amazonian forest in the hydrological cycle of the region has received a fair amount of attention in recent decades. The ratio of the amount of precipitation that comes from a local region through evaporation to the total observed is known as the "recycling" ratio, and has been 
the subject of study since the mid-1970s (see Molion, 1975; Salati, 1987, and references therein). This ratio varies substantially, assuming a generally lower value in winter and a generally higher value in summer, when large-scale transport diminishes in importance. Precipitation recycling is the contribution of evaporation from within a region to precipitation in that same region. The recycling rate is a diagnostic measure of the potential interaction between land surface hydrology and regional climate. The recycling of local evaporation and precipitation by the forest accounts for a sizable portion of the regional water budget, and because large areas of the basin are sensitive to the effects of deforestation there are grave concerns about how such disruptions to the land surface may affect the hydrological cycle in the tropics. Eltahir and Bras (1994), Brubaker et al. (1993), Costa and Foley (1999), Trenberth (1999), Nóbrega et al. (2005), Marengo et al. (2006), Silva (2009), Van der Ent et al. (2010) and Satyamurty et al. (2013a), among others have estimated an annual mean recycling rate of about 20 to $35 \%$, less than the previous estimates made by Molion. Dirmeyer et al. (2009) combines the characteristics of persistence of soil moisture anomalies, strong soil moisture regulation of evaporation rates, and reinforcement of water cycle anomalies through recycling, and they demonstrated that there are signs of land-atmosphere feedback throughout most of the year in the Amazon region. More recently, in their study of the role of land surface processes and land use changes in regional circulation, Angelini et al. (2011) found that rain in the Amazon comes primarily from large-scale weather systems from the tropical Atlantic that do not rely on local evaporation. Previous studies by Gat and Matsui (1991) and references quoted therein investigate the moisture recycling in the Amazon region using the isotopic composition of precipitation over the region. Their results suggest that an isotopically fractionated evapotranspiration flux contributes to the atmospheric water balance over the region, and they show that $20-40 \%$ of the total evapotranspiration flux is accompanied by an isotopic fractionation, such as by evaporation from an open water surface.

Almost all the studies concerning moisture transport over the Amazon are based on Eulerian methodologies (e.g. Arraut and Satyamurty, 2009; Arraut et al., 2012; Satyamurty et al., 2013a, and references therein). According to these authors, the moisture flux from the equatorial Atlantic associated with the trade winds is the main remote moisture source for the Amazon. The climatological role of the subtropical Atlantic Ocean as a moisture source for the Amazon was also reported in the Lagrangian 5-year periodic analysis developed by Stohl and James (2005), as well as in the recent results on the role of the oceanic regions published by Gimeno et al. (2013). At the same time, the air mass trajectories crossing the Amazon capture moisture destined for other parts of the continent, particularly the La Plata Basin and central Brazil (e.g. Roads et al., 2002; Marengo, 2005; Drumond et al., 2008; Arraut and Satyamurty, 2009). Van der Ent et al. (2010) verified that the La Plata Basin relies on evaporation from the Amazon forest for $70 \%$ of its water resources. Bosilovich and Chern (2006) suggested that evaporation from the Amazon Basin exhibits slight interannual variations, and in turn the interannual variation of precipitation recycling is therefore related to atmospheric moisture transport from the tropical South Atlantic Ocean.

The role of vegetation in supplying moisture transport over the Amazon was discussed by Spracklen et al. (2012), who found that air that passes over extensive vegetation subsequently releases at least twice as much rain a few days later than air that passes over less vegetated areas. More recently, Makarieva et al. (2013) suggested that the water vapour delivered to the atmosphere via evaporation from forests represents a store of potential energy available to accelerate air and drive winds. This implies that changes in precipitation over the Amazon are due to a combination of different regional processes and interactions that are partly influenced by large-scale circulation and partly influenced by local water sources from forests and soil moisture.

Several of the drought episodes documented in the Amazon occurred during intense El Niño episodes, such as those registered in 1926, 1983, 1997-1998, and 2010, with reductions in discharge in the main rivers as well as serious ecological and economic damage due to fire events (e.g. Williams et al., 2005; Sternberg, 1987; Marengo et al., 2008, 2013; Richey et al., 1989). The influence of the El Niño Southern Oscillation (ENSO) in the interannual variability of the Amazon climate may also be felt due to its role in positioning the Intertropical Convergence Zone (ITCZ) (e.g. Coe et al., 2002; Uvo et al., 1998, Marengo et al., 2013). Although the impact of the ENSO on the Amazon precipitation and river discharge has been investigated extensively, its influence on the moisture transport into and out of the basin has not been explored in any detail. It is known that during ENSO events, changes in the precipitation regime are greater during the Amazon rainy season, and they are not homogeneous over the basin (Foley et al., 2002; Marengo et al., 2008). As mentioned by Grimm and Ambrizzi (2009, and references therein), during El Niño episodes, the tropical convection is shifted from western Pacific towards central and eastern Pacific. Consequently, the Pacific Walker cell is weakened because the induced anomalous circulation along the equator is opposite to the climatological circulation. As the anomalous subsidence in the Walker cell associated with anomalous convection over the eastern Pacific occurs over northern South America and Atlantic Ocean, the two smaller cells connected with the continent are strongly affected, especially by the weakening of the ascending branch over the Amazon region. The reduction of the convection over this region also reduces the regional Hadley circulation. On the other hand, the Hadley circulation is strengthened over the central/eastern Pacific. During La Niña episodes the changes are nearly opposite. 
Nevertheless, not all El Niño events are related to drought in the Amazon (Marengo et al., 2013). Recent studies have also pointed to the importance of the tropical Atlantic (TA) in the modulation of the Amazon climate (Yoon and Zeng, 2010), as observed during the 2005 and 2010 drought events (e.g. Marengo et al., 2008; Lewis et al., 2011), as well as during the 2012 flood in the Amazon River (Satyamurty et al., 2013b). According to Servain (1991), the Atlantic Meridional Mode (AMM), also known as the meridional sea surface temperature (SST) gradient, may be considered one of the main low-frequency SST variability modes in the tropical Atlantic, and its extreme episodes are characterised by an anomalous interhemispheric gradient structure. Associated with these anomalous SST patterns are changes in the trade winds, presenting as anomalous surface winds crossing the equator, and the Atlantic ITCZ is displaced towards the warmer SST anomalies.

Given the importance of the Amazon Basin in the moisture budget, the present paper aims to investigate the annual cycle of the main sources of moisture for the Amazon Basin, as well as its own contribution as a moisture source for the rest of the continent, through the use of the Lagrangian method developed by Stohl and James $(2004,2005)$. This approach diagnoses net changes in specific moisture along trajectories and was previously successfully applied in studies of sources of moisture for different regions around the world, including South America, such as the Orinoco Basin (Nieto et al., 2008), the South American Monsoon System (SAMS) and northeastern Brazil (Drumond et al., 2008, 2010). Here we make use of a 33-year data set that allows us to corroborate the climatological aspects highlighted by the 5-year analysis of Stohl and James (2005), and to explore aspects of interannual variability in a novel way. The larger temporal domain allows the investigation of the changes observed during years characterised by extreme conditions of the ENSO and of the $\mathrm{AMM}$ on the moisture transport over the region.

\section{Data and methods}

The Amazon Basin is shown in Fig. 1. The spatial limits adopted for this domain are in accordance with those defined by the Observatoire de Recherche en Environnement (ORE HYBAM) from the website http://www.ore-hybam.org/index.php/por/Dados/ Cartografia/Bacia-amazonica-hidrografia.

A detailed intercomparison of the different methods used to establish source-sink relationships for atmospheric water vapour is given by Gimeno et al. (2012). There are different methods, namely "analytical and box models", "physical water vapour tracers" (isotopes) and "numerical water vapour tracers" (including the Lagrangian and Eulerian approaches). All of them provide useful and interesting information that aids the analysis and the results are subject to assumptions made and to the type and accuracy of the data used. The "box models" allow the identification of the moisture inflow and outflow given defined lateral boundaries, but they give no information about the physical processes that occur within the box itself. The use of isotopes depends on the sensitivity of the isotopic signal. The Eulerian methodology is widely used due its simplicity but it is not simple to extract the link between the precipitation over a region and the moisture source using this method. The Lagrangian approach provides realistic traces of air parcels, enabling the trajectories to be followed and source-receptor relationships to be established. In that way, the most recently developed Lagrangian techniques are being extensively applied for evaluating the origin of the water that precipitates over a continental area (e.g. Stohl and James, 2005; Dirmeyer and Brubaker, 2007; Gimeno et al., 2013; Knippertz et al., 2013).

The present study is based on the method developed by Stohl and James (2004, 2005), which uses the FLEXPART V9.0 Lagrangian particle dispersion model and ERA-Interim reanalysis data (Dee et al., 2011) to track changes in atmospheric moisture along trajectories. The model run considers the atmosphere to be divided homogeneously into threedimensional finite elements (hereafter "particles"), each representing a fraction of the total atmospheric mass (Stohl and James, 2004). These particles are advected using the threedimensional wind data, with superimposed stochastic turbulent and convective motions. The increases $(e)$ and decreases $(p)$ in moisture along any trajectory can be calculated through changes in $(q)$ with time $(e-p=m \mathrm{~d} q / \mathrm{d} t)$, with $(m)$ being the mass of the particle. By summing $(e-p)$ for all the particles residing in the atmospheric column over an area we obtain the aggregated $(E-P)$ field, where the surface freshwater flux $(E)$ is the evaporation rate and $(P)$ is the precipitation rate per unit area. It should be noted that this approach has the disadvantage that it cannot calculate evaporation and precipitation separately, but only the fluxes into or out of the tracked air mass. The method is mostly limited by the accuracy of the trajectories and also by the use of a time derivative of humidity (unrealistic fluctuations in humidity could be considered moisture fluxes). However, such random errors may cancel each other out given the large number of particles in an atmospheric column. A detailed review of this methodology against other Eulerian and Lagrangian approaches was presented by Gimeno et al. (2012).

The FLEXPART data set used in this work comes from a global simulation in which the entire global atmosphere was divided into approximately 2.0 million particles. Following the seminal works of Stohl and James $(2004,2005)$ and the subsequent studies based on the same Lagrangian methodology (e.g. Nieto et al., 2008; Drumond et al., 2008; Gimeno et al., 2013), we limited the transport time to 10 days. While the 10-day period of tracking is somewhat arbitrary, it is about the average residence time of water vapour in the atmosphere (Numaguti, 1999). The tracks were computed using ERAInterim reanalysis data available at six-hour intervals (00:00, 06:00, 12:00 and 18:00 UTC), at a $1^{\circ}$ horizontal resolution, 

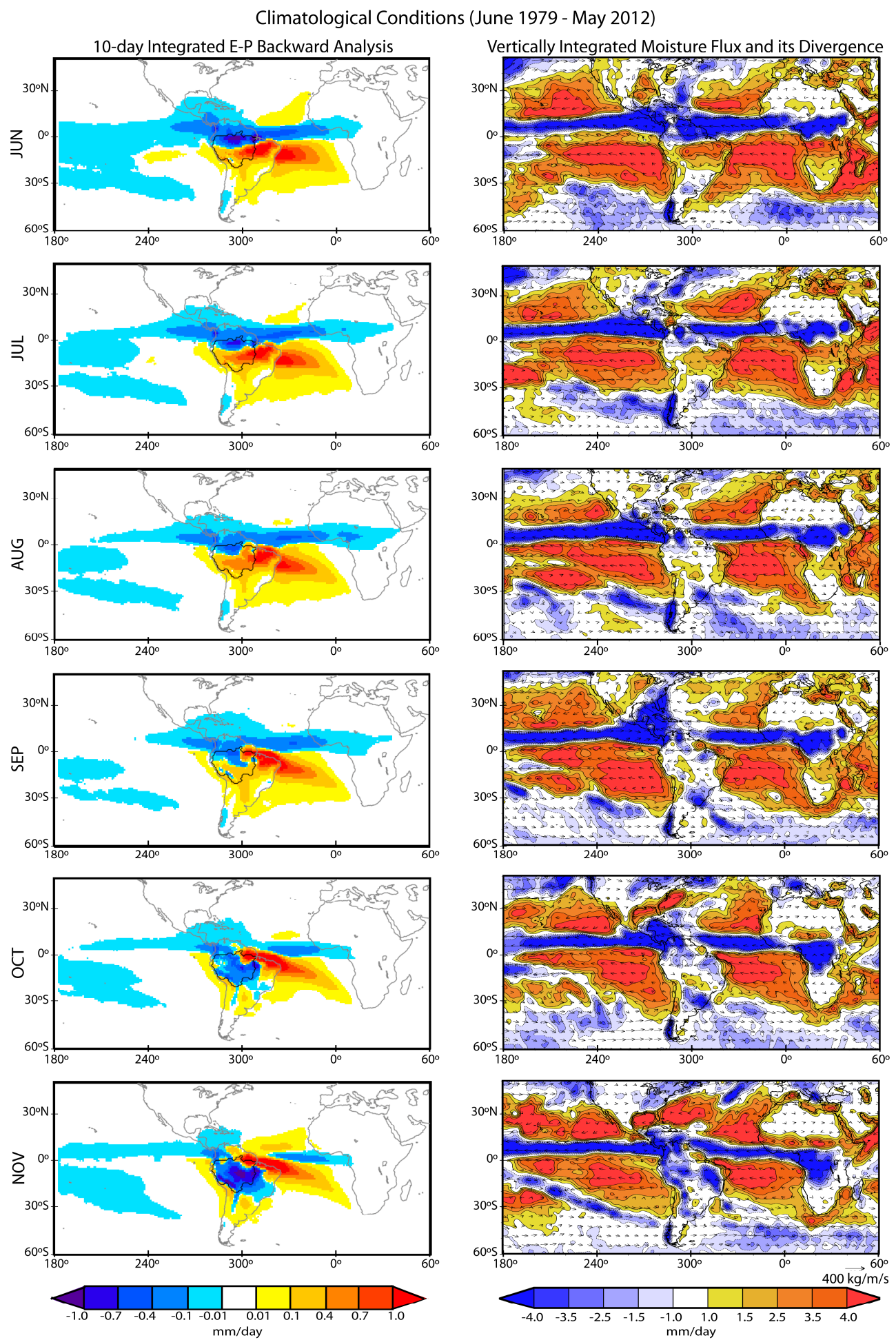

Figure 1. Left-hand column: climatological monthly 10-day integrated $(E-P)$ values observed for the period June 1979-May 2012, for all the particles bound for the Amazon Basin, determined from backward tracking. Red (blue) colours represent regions acting as moisture sources (sinks) for the tracked particles. The black contour line indicates the basin area. Right-hand column: climatological monthly vertically integrated moisture flux values (vectors; measured in $\mathrm{kg} \mathrm{m}^{-1} \mathrm{~s}^{-1}$ ) and respective divergence (shade; measured in mm day ${ }^{-1}$ ). Data obtained from ERA-Interim. 
Climatological Conditions (June 1979 - May 2012)
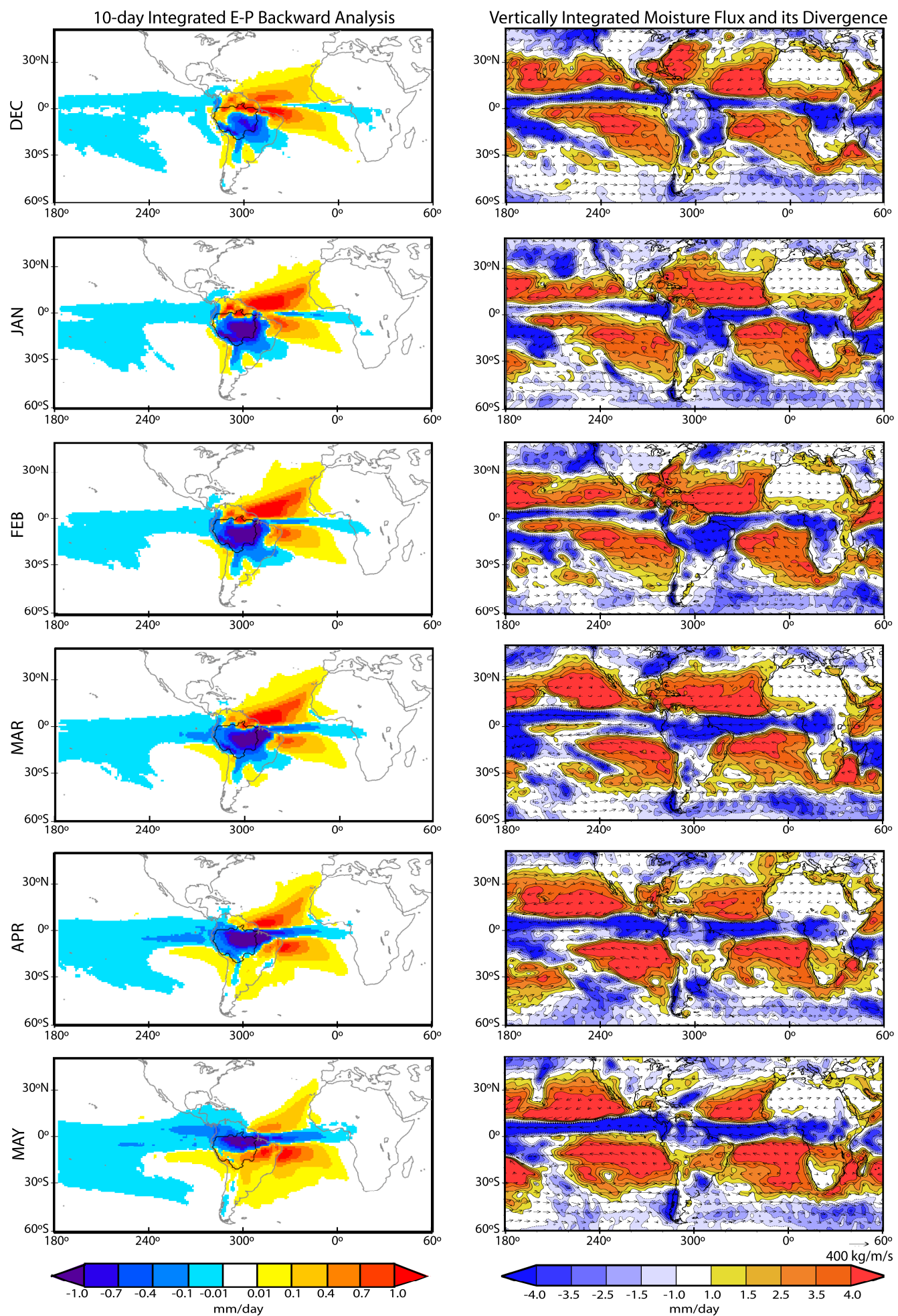

Figure 1. Continued. 
and at a vertical resolution including 61 vertical levels, from 0.1 to $1000 \mathrm{hPa}$. The analysis covers a 33-year period, from June 1979 to May 2012. As Gimeno et al. (2013) pointed out, the FLEXPART model requires consistent high-quality wind and humidity data, meaning that its application to previous years is rather difficult (i.e. prior to the significant decrease in the errors in these variables, particularly over the oceans, due to the inclusion of satellite data in about 1979 (Bengtsson et al., 2004)).

The first question we intend to explore through a Lagrangian analysis is where does the atmospheric moisture observed over the Amazon come from? To answer this, a backward analysis allows us to identify where the particles gain humidity along their trajectories towards the target area, regions hereafter denominated as sources of moisture. From this set of experiments, in all grid points where $E-P>0$ we know that air particles located within that vertical column and bound towards the target area gain moisture. A complementary question would be what is the final destination of the moisture carried by moisture transport along air trajectories leaving the Amazon? In this case, a forward analysis may identify all trajectories crossing the basin, and if we follow them we will find where they lose moisture. In this case, the $(E-P<0)$ values indicate the most important sinks of moisture, i.e. where the atmospheric moisture budget of the tracked air particles is characterised by a loss of moisture. All figures show $E-P$ integrated over the whole tracking period (10 days) at the monthly scale, allowing us to study the annual cycle. It is important to clarify that the applied methodology does not guarantee that the moisture gained by an air particle when crossing a source will reach the target region. This depends on the interaction with all air particles present in the atmospheric column. In addition, the water may precipitate if the air particle crosses a sink region before reaching the target. Herein we refer to the austral seasons (summer is from December to February, autumn from March to May, winter from June to August, and spring from September to November).

Given our climatological overview of the atmospheric branch of the hydrological cycle over the Amazon region, our next question is were there changes in the moisture transport over the Amazon during years characterised by extremes of ENSO? This theme will be explored through the technique of composite differences. The ENSO events were obtained from the NOAA/CPC (Climate Prediction Center) Oceanic Niño Index (ONI) (www.cpc.noaa.gov/products/ analysis_monitoring/ensostuff/ensoyears.shtml). The index values were calculated as the 3-month running mean of Extended Reconstructed Sea Surface Temperature (ERSST) v3b SST anomalies (Smith et al., 2008) in the Niño 3.4 region $\left(5^{\circ} \mathrm{N}-5^{\circ} \mathrm{S}, 120^{\circ} \mathrm{W}-170^{\circ} \mathrm{W}\right)$ referred to by Trenberth (1997), and the ONI is based on the 1981-2010 climatology. According to CPC, extreme ENSO episodes occur when the threshold of $\pm 0.5^{\circ} \mathrm{C}$ for the ONI is exceeded on a minimum of five consecutive overlapping seasons. There- fore, in order to select a whole year as El Niño or La Niña, we considered those years when the threshold was exceeded a minimum of five times consecutively from June in year 0 to May in year 1 (for a given ENSO cycle). Ten El Niño episodes (1982/83, 1986/87, 1987/88, 1991/92, 1994/95, 1997/98, 2002/03, 2004/05, 2006/07, 2009/10) and eleven La Niña events (1984/85, 1988/89, 1995/96, 1998/99, 1999/00, 2000/01, 2005/06, 2007/08, 2008/09, 2010/11, 2011/12) were selected for the period 1979-2012. Although the February-May (FMAM) season was defined to be the peak season for rainfall anomalies in the Amazon (Marengo et al., 2013b), the analysis was carried out at a monthly scale considering the annual cycle from June in one year to May in the following year (June/0 to May/1). This allows us to identify possible changes in moisture transport during the months before the peak season, and also to standardise the presentation of the results according to the ENSO cycle. We followed the methodology proposed by Wei et al. (2012) to evaluate the statistical significance of the composite differences using the bootstrap method, applied in our case with 1000 interactions at the $90 \%$ confidence level. We repeated the calculation of the difference of two samples (one with 10 elements, and the other with 11) selected at random (a total of 21 elements) from the 33-year climatology a total of 1000 times. To be considered significant, the absolute value of the composite of the differences had to be larger than $90 \%$ of the 1000 randomly obtained differences.

Finally, the technique of composite differences was also applied to investigate the influence of the AMM over the moisture transport into and out of the Amazon. We calculated the AMM index following the method applied by Marengo et al. (2013), using the HadISST1 monthly SST data set (Rayner et al., 2003) available at a $1^{\circ}$ regular horizontal resolution to calculate the difference in the standardised SST anomalies averaged over the tropical North Atlantic $\left(12-27^{\circ} \mathrm{N}, 20-50^{\circ} \mathrm{W}\right)$ and the tropical South Atlantic $\left(0-15^{\circ} \mathrm{S}, 0-15^{\circ} \mathrm{W}\right)$ subregions. Those years with absolute AMM values averaged over FMAM higher than one standard deviation were considered extremes. AMM+ episodes are herein defined as those presenting positive SST anomalies over the North Atlantic and negative ones over the South Atlantic. The opposite pattern occurs during AMM- events. Applying the same calendar used to study the impacts of the ENSO, the differences in the composites were calculated on a monthly scale considering the annual cycle from June in year 0 to May in year 1. Considering the months FMAM to belong to year 1, seven AMM+ episodes (1979/80, 1980/81, 1982/83, 1991/92, 1996/97, 2003/04, 2009/10) and seven AMM - events (1983/84, 1984/85, 1985/86, 1988/89, $1993 / 94,1994 / 95,2008 / 09$ ) were selected from the period 1979-2012. To evaluate the statistical significance of the composite differences using the bootstrap method, the calculation of the difference considered two samples with 7 elements, each selected at random (a total of 14 elements) from the 33-year climatology. 
Summarising, the results presented in the next section are organised into three topics. An analysis of the climatological annual cycle of the transport of moisture into and from the Amazon is discussed in the Sect. 3.1. The technique of composite differences is then applied to investigate how ENSO (Sect. 3.2) and AMM (Sect. 3.3) episodes may affect the transport of moisture over the basin.

\section{Results}

\subsection{Annual cycle}

Figure 1 shows the monthly values of 10-day integrated atmospheric moisture budget $(E-P)$ obtained via backward trajectories from the Amazon Basin for the 33-year period June 1979-May 2012. The backward experiment allows us to identify where the tracked particles gain humidity along their trajectories towards the target area. The areas characterised by red colours represent regions where $(E-P)>0$, meaning that evaporation exceeds precipitation in the net moisture budget considering only those air particles located within that vertical column and travelling towards the target area, and these regions act as moisture sources for the tracked particles. In the opposite sense, the blue colours represent areas where $(E-P)<0$, which are those regions where precipitation exceeds evaporation in the net moisture budget of the tracked air particles (moisture sinks). Finally, the white areas represent regions where $(E-P)$ values are low.

We now describe the temporal evolution of the distribution of the moisture sources for the Amazon Basin throughout the year. The ERA-Interim vertically integrated moisture flux (VIMF) and its divergence fields were provided together with the Lagrangian backward analyses in order to help the reader to visualise the moisture transport under an Eulerian perspective. Although not shown together, the VIMF fields presented with the backward figures may be useful to interpret the forward analyses as well. The red colours configured during the period June-August in Fig. 1 suggest the predominance of the contribution from the southern Atlantic Ocean, compared with those from northeastern Brazil, the southern Amazon, and the La Plata Basin. It seems that tropical and subtropical South America provide some moisture during the austral winter. Apart from the La Plata Basin, the evaporative sources described above coincide quite well with the areas of divergence of VIMF (right-hand column). One can identify some predominantly evaporative sources over the North Atlantic (yellow colours, left-hand column), but our methodology cannot be used to check whether the moisture received by the particles crossing this region will precipitate when crossing the ITCZ (blue equatorial areas) before reaching their target. From September onwards, the moisture sink areas (left-hand column) and the convergence of the VIMF observed over the northwestern Amazon expand towards southeastern Brazil and the La Plata Basin, and per-
Moisture Contribution from the NA and SA regions to the Amazon Basin
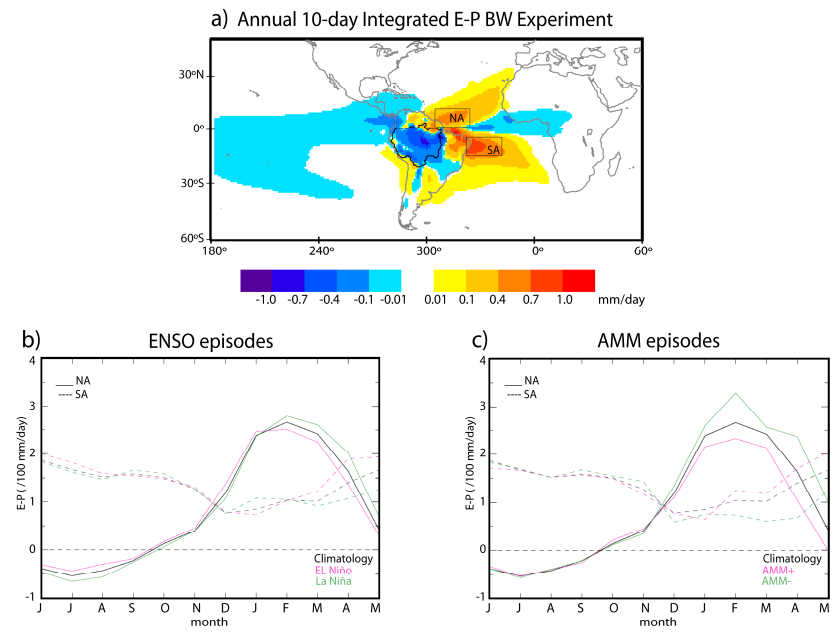

Figure 2. (a) Climatological annual average of 10-day integrated $(E-P)$ obtained through the backward Amazon experiment for the period June 1979-May 2012. The black contour line indicates the basin area, and the boxes NA and SA indicate the source areas selected. (b) The annual cycle of the monthly values of 10-day $(E-P)$ shown in Fig. 1 and integrated over the NA (continuous line) and SA (traced line) source areas indicated in (a). Black lines represent the 33-year average values, while pink and green lines indicate the average of the El Niño and La Niña events, respectively. (c): as (b), but the pink and green lines indicate the average of the AMM+ and $\mathrm{AMM}-$ events, respectively.

sist until March. The persistence of these moisture sink regions through the extended austral summer coincides with the active phase of the SAMS. From November to April, the evaporative sources and the divergence of the VIMF intensify over the tropical North Atlantic Ocean and reach the northern boundary of the basin, accompanied by a moisture flux from the Northern Hemisphere towards the target region. The displacement northwards of the equatorial sink during May is accompanied by a weakening of this evaporative region.

From the foregoing, Fig. 1 suggests the role of the TA as the most important remote source of moisture for the Amazon Basin, probably associated with the seasonal migration of the ITCZ and the confluence of trade winds. It seems that there is an increase in the moisture contribution from the North or South TA during the respective winter associated with the intensification of the hemispheric trade winds. Nieto et al. (2008) also reported a similar annual cycle in the role of TA as a source of moisture for the Orinoco Basin, to the north of the Amazon. Some moisture from the South American Pacific coast also reaches the Amazon throughout the year. The Amazon receives some moisture from subtropical South America, probably transported by frontal systems. Figure 1 also suggests the contribution of local evaporative processes in the Amazon as a moisture source for the basin throughout the year. 
To illustrate the annual cycle of the contribution of the TA in more detail, we divided the region into two hemispheric subareas having the same spatial dimensions: the North and the South TA (North Atlantic (NA): $55-35^{\circ} \mathrm{W}$ and $2-12^{\circ} \mathrm{N}$; South Atlantic (SA): $37-17^{\circ} \mathrm{W}$ and $4-14^{\circ} \mathrm{S}$ ), as indicated in Fig. 2a. The technique of percentiles was applied to the annual averages of $(E-P)$ for both the backward and the forward experiments (Figs. 2a and 4a, respectively) in order to determine the boundaries of the areas of interest. Although the definition of the threshold was arbitrary, we believe that this statistical procedure is valid for identifying the regions of maximum absolute $(E-P)$ values. To provide a standardised analysis, we chose the contour line of $0.4 \mathrm{~mm}_{\text {day }}{ }^{-1}$, which corresponds to the $96 \%$ percentile of all positive values shown in Fig. 2a, as well as to the $95 \%$ percentile of all negative values configured in the $(E-P)$ annual average from the forward experiment (Fig. 4a), which we discuss later. The location of the NA and SA boxes coincide with two regions of high values of continental evaporation cycling ratio (Ec > 0.5) identified by Van der Ent and Savenije (2013), which represents the fraction of the evaporation that is transported to and precipitates over continents.

Figure $2 \mathrm{~b}$ shows the monthly averages of the 10-day ( $E-$ $P$ ) backward trajectories calculated in Fig. 1 and integrated over both source areas. Recalling that we define a region as a moisture source when it presents positive $(E-P)$ values, it seems that the NA (continuous black line) contributes moisture from October to May. During this period, the convergence of VIMF associated with the ITCZ migrates southwards, and the northern trade winds carrying moisture cross the NA and reach the South American coast (Fig. 1, righthand column). The negative $(E-P)$ values characterising the NA from June to September suggest that this region does not act as a moisture source for the Amazon Basin during these months. In our methodology, this means that precipitation prevails over evaporation in the atmospheric moisture budget integrated over NA during this period. This may be the case because the positioning of the VIMF convergence associated with the Atlantic ITCZ in these months (Fig. 1, righthand column) coincides with the NA box. On the other hand, the contribution of the SA (traced black line) occurs all year and reaches its maximum during the austral winter, when the VIMF divergence over the South Atlantic is greater and expands into the tropical continent, enhancing the moisture flux towards the Amazon (Fig. 1, right-hand column). Our results compare well with those of Bosilovich and Chern (2006) and of Van der Ent and Savenije (2013). Bosilovich and Chern (2006) made use of a 50 year atmospheric general circulation model simulation including water vapour tracers to investigate the water budget for the Amazon River and its respective sources of water. These authors also noted the importance of the South Atlantic Ocean in providing moisture to the Amazon Basin throughout the year, except during the austral summer when the contribution of the tropical North Atlantic dominates. Using a different methodology from that applied in the present study to identify the oceanic sources based on an atmospheric backtracking analysis of continental precipitation, Van der Ent and Savenije (2013) also verified not only the importance of the TA in providing moisture to South American precipitation, but also a similar variability of the contributions from the North and South TA throughout the year.

The role of the Amazon as a moisture source can be inferred from the 10-day $(E-P)$ forward trajectories from the basin for the 33-year period presented in Fig. 3. The method identifies those particles that leave the basin and follows them to the point at which they lose moisture. Only negative values are shown in order to clarify the moisture sinks. The white areas represent regions where the $(E-P)$ fields have low or positive values. We will now briefly describe the temporal evolution. During the austral winter months the major moisture sinks of the air particles that leave the basin are located over southeastern South America and over northern South America and adjacent equatorial regions. These sinks coincide with two regions of convergence of VIMF over the continent: one over the subtropics and another associated with the ITCZ (Fig. 1, right-hand column). From September to January, the moisture transport towards the equatorial latitudes weakens in association with the weakening of the convergence of the VIMF (Fig. 1, right-hand column), while the moisture sinks and the convergence of the VIMF areas expand over tropical and subtropical South America. During the austral autumn, the convergence of the VIMF and the sink regions reduce again towards both the subtropics of the continent and the equatorial band.

In accordance with the VIMF analysis shown in Fig. 1 (right-hand column) and in view of previous results obtained using different methodologies (e.g. Roads et al., 2002; Marengo, 2005, 2006; Drumond et al., 2008; Arraut and Satyamurty, 2009; Dirmeyer et al., 2009; Van der Ent et al., 2010; Keys et al., 2012; Spracklen et al., 2012; Bagley et al., 2014), the contribution from the basin predominantly extends towards southeastern South America (including the La Plata Basin, hereafter LP). Moisture is also transported towards southeastern Brazil during the austral spring and the summer months, a period characterised by the active phase of the SAMS (Vera et al., 2006). The Orinoco Basin, the Atlantic ITCZ, and part of the Caribbean Sea also receive some moisture from the Amazon region, except during the austral summer. This can probably be explained in terms of the positioning of the VIMF convergence associated with the ITCZ in the northern latitudes for most of the year, enhancing the moisture transport from Amazon towards these sinks (Fig. 1, right-hand column). Using a different data set and analysing a 5 year period, Nieto et al. (2008) verified some contributions of moisture from the Amazon into the Orinoco during the months of JJAS, a period characterised by drought conditions in the southern Amazon. Moisture from the Amazon is also transported towards parts of the Pacific ITCZ and the Western Hemisphere warm pool (Drumond et al., 2011, and 

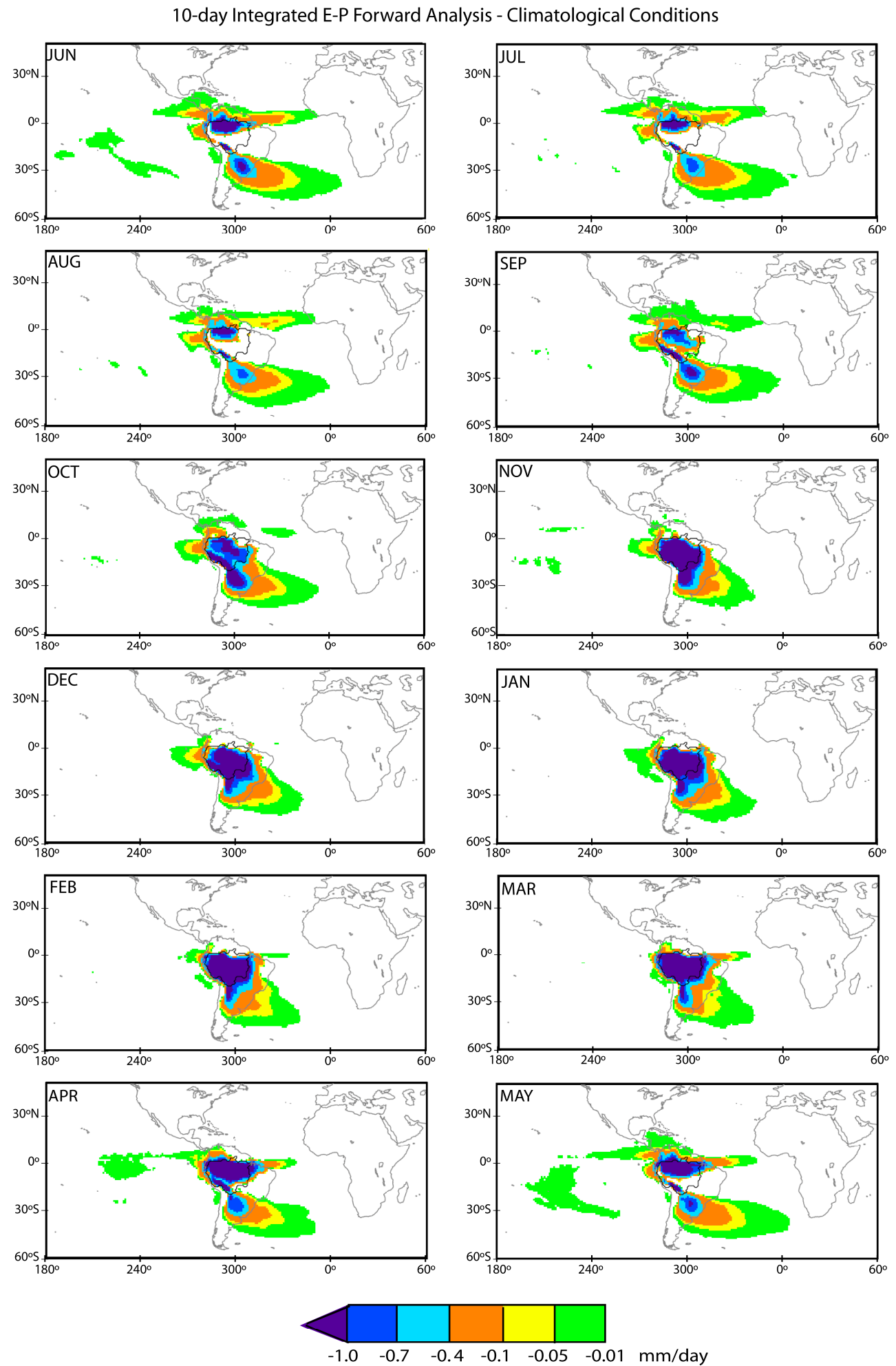

Figure 3. Climatological monthly 10-day integrated $(E-P)$ fields obtained through the forward Amazon experiment for the period June 1979-May 2012. Only negative values are shown in order to emphasise the sink regions. Black contour line indicates the basin area. 


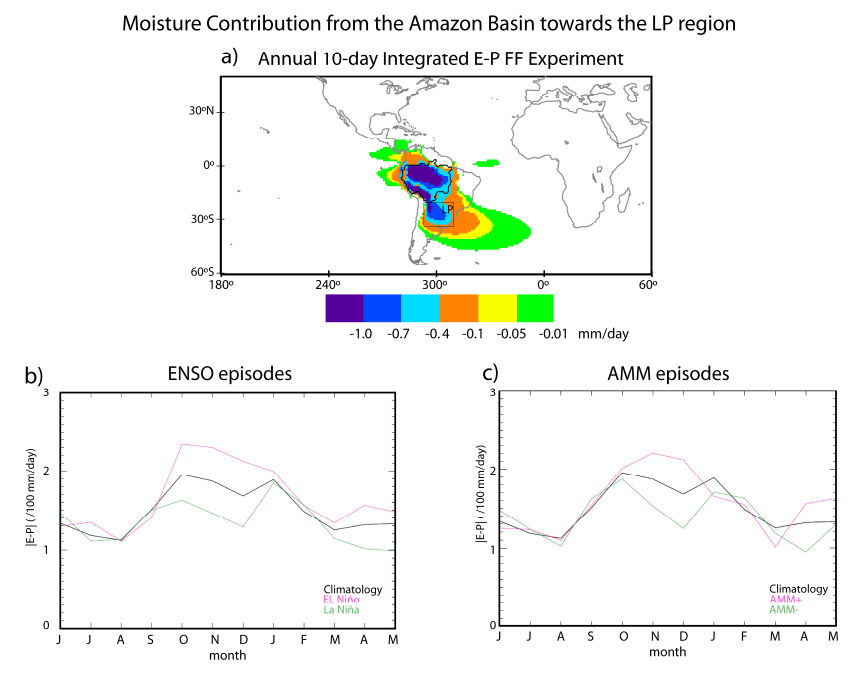

Figure 4. (a) Climatological annual average of 10-day integrated $(E-P)$ obtained through the forward Amazon experiment for the period June 1979-May 2012. Black contour line indicates the basin area, and the LP box indicates the sink area selected. (b) The annual cycle of the monthly absolute values of 10-day $(E-P)$ shown in Fig. 3 and integrated over the LP sink area indicated in (a). Black lines represent the 33-year average values, while pink and green lines indicate the average of the El Niño and La Niña, respectively. (c): as (b), but the pink and green lines indicate the average of the $\mathrm{AMM}+$ and $\mathrm{AMM}-$ events, respectively.

references therein) regions. Figure 3 also suggests some recycling throughout the year, with local moisture sink areas expanding over the central and southern basin from September to April, while reducing in extent towards the northern and southern basin from May to August.

In order to investigate the annual cycle of the contribution from the Amazon towards the LP region, a similar analysis to that applied to the backward case was performed for the forward case. As previously explained, the boundaries of the LP box $\left(67-50^{\circ} \mathrm{W}, 20-34^{\circ} \mathrm{S}\right)$ were defined according to the contour line of $-0.4 \mathrm{~mm} \mathrm{day}^{-1}$ in the 33-year annual average of the 10-day integrated $(E-P)$ values of the forward trajectories from the Amazon Basin (Fig. 4a). Here, $-0.4 \mathrm{~mm} \mathrm{day}^{-1}$ corresponds to the $95 \%$ percentile of all the negative values obtained. We integrated the monthly averages of the 10day $(E-P)$ forward trajectories shown in Fig. 3 over the LP area, and in order to present the results as clearly as possible Fig. $4 \mathrm{~b}$ shows the absolute values of $(E-P)$, because all values obtained over the area are negative $((E-P)<0$, meaning that LP acts as a sink of moisture from the Amazon throughout the year). Figure $4 \mathrm{~b}$ suggests a higher-frequency variability of the moisture contribution (presenting something like a seasonal cycle) superimposed on an annual cycle with maximum values during the austral spring/summer and minima during autumn/winter. It shows maximum contributions during June (a secondary maximum), October and January, and minima in August, December (a secondary minimum) and
March. The migration of the ITCZ associated with the development of the SAMS may explain the annual cycle of the moisture contribution from the Amazon to LP. According to previous studies (e.g. Moura and Shukla, 1981; Folland and Parker, 1986), the Atlantic ITCZ presents a seasonal latitudinal migration coupled with the annual cycle of the spatial distribution of the maximum SST observed over the TA, and it reaches its maximum northward (southward) displacement during austral spring (autumn). However, the causes of this near-seasonal variability remain unclear for us and merit further attention. The VIMF analysis shown in Fig. 1 suggests some monthly variability in the moisture flux from the Amazon towards LP, which then leads to the configuration of different patterns of convergence or divergence of VIMF over the target region throughout the year.

\subsection{Role of ENSO on the moisture transport over the Amazon Basin}

Figure 5 shows the differences in the composites of moisture sources of the Amazon Basin for El Niño and La Niña events. Both composite fields were obtained considering only positive $(E-P)$ values (source regions) obtained in the backward analysis. Pink (green) colours indicate regions where their contribution as a source intensified during El Niño (La Niña) events. From the results it is clear that the moisture contribution from the equatorial Atlantic was enhanced during all months of an El Niño cycle. In comparison to La Niña episodes, it seems that the contribution from the tropical and subtropical Atlantic was weakened during an El Niño cycle. The differences in the VIMF from both composites (Fig. 5, right-hand column) show enhanced VIMF divergent conditions over the equatorial Atlantic during the El Niño episodes selected, accompanied by an intensified moisture transport from there towards the basin. However, the enhanced VIMF divergence expanding towards tropical South America probably inhibited the precipitation of the moisture carried from the ocean to the Amazon. We believe that the configuration of these patterns may be understood through the displacement of the Walker cell eastwards as observed during an El Niño cycle, favouring subsidence over tropical South America. As a probable consequence of the presence of this intensified subsidence over the continent, the VIMF differences suggest the displacement of the moisture flux convergence associated with the Atlantic ITCZ northwards during April and May (year 1), probably associated with the inhibition of the latitudinal ITCZ migration southwards. The known importance of the ENSO in modulating South American precipitation through its associated changes in atmospheric circulation (e.g. Kousky et al., 1984; Ropelewski and Halpert, 1987) was also reported in a correlation analysis by Van der Ent and Savenije (2013).

Looking at La Niña cycle (Fig. 5, green colours), from June to October (year 0) there was an enhancement of the South Atlantic source associated with a higher contribution 

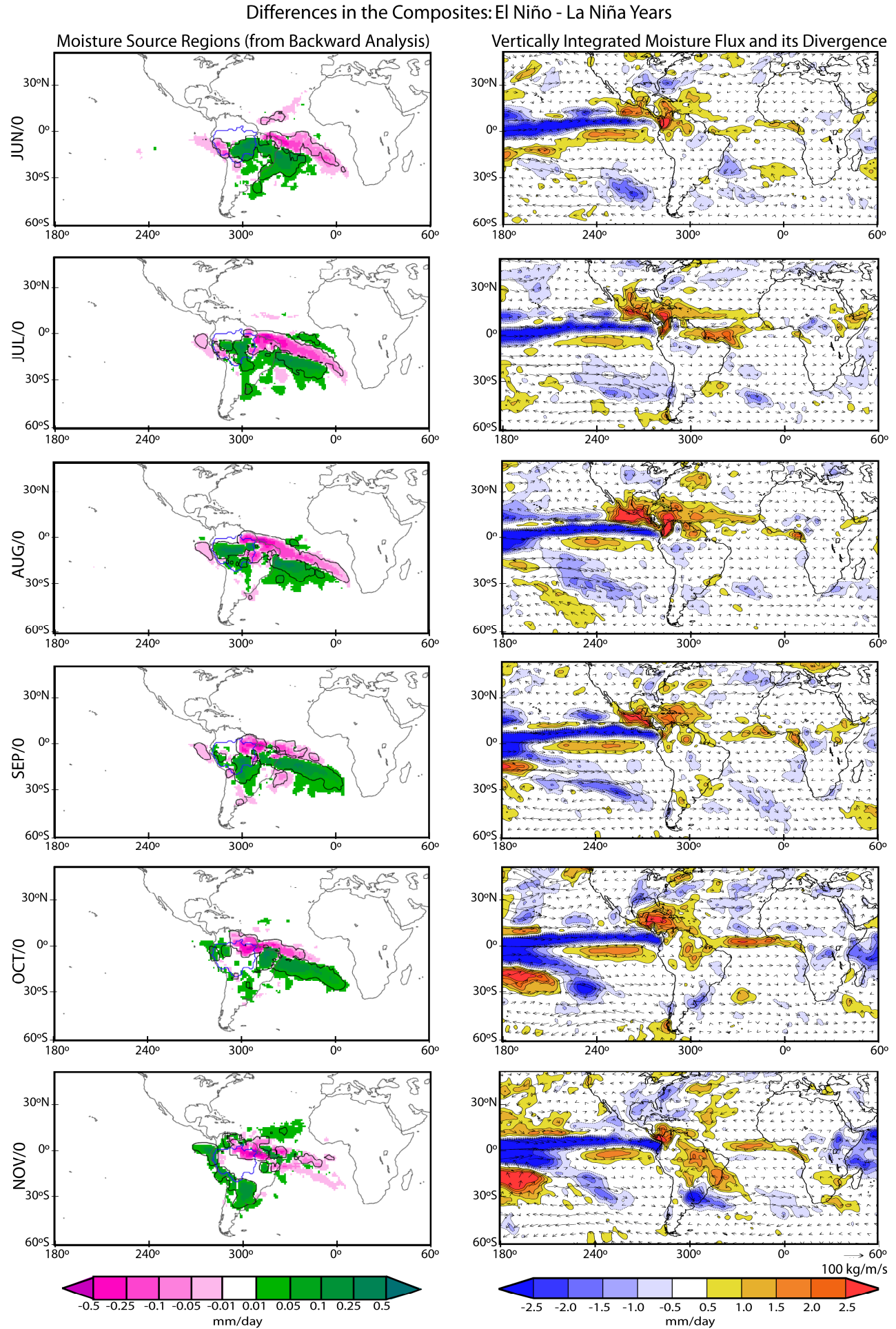

Figure 5. Left-hand column: monthly differences of composites of moisture sources of the Amazon Basin (considering only positive $E-P$ values in the composites using backward analysis) for extreme ENSO episodes. Black contour lines indicate regions where the differences are significant at the $90 \%$ level according to the bootstrap test. Pink (green) colours indicate regions where the sources are more intense during El Niño (La Niña) years. Blue contour line indicates the basin area. Right-hand column: monthly differences in the vertically integrated moisture flux (vectors; measured in $\mathrm{kg} \mathrm{m}^{-1} \mathrm{~s}^{-1}$ ) and its divergence (shade; measured in mm day ${ }^{-1}$ ) between the composites for El Niño and La Niña years. Data obtained from ERA-Interim. 
Differences in the Composites: El Niño - La Niña Years
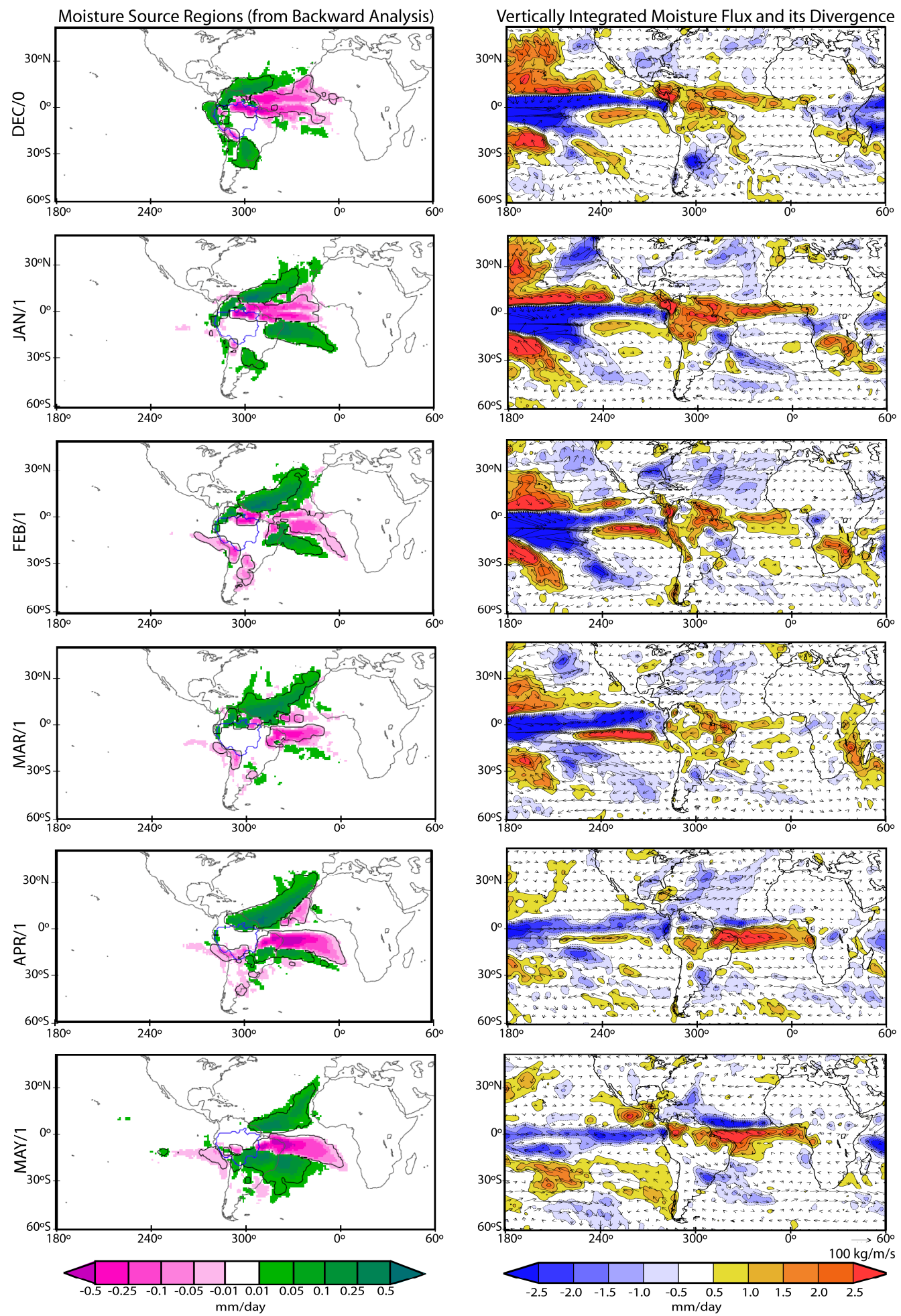

Figure 5. Continued. 
from the southern Amazon. These anomalous patterns weakened during November and December (year 0), being replaced by increased sources over the La Plata Basin, over the western continent, and over the northern Atlantic. During January and February (year 1) the anomalous sources weakened over the western continent, while they were enhanced over the tropical North and South Atlantic domains. The anomalous North Atlantic source persisted until May (year 1), while the anomalous South Atlantic reduced in size during February-April (year 1). The anomalous contribution from the La Plata Basin disappeared from February (year 1) onwards.

If we analyse the variability of $(E-P)$ integrated over the NA and TA boxes during the ENSO cycle using a composite analysis (Fig. 2b, green and pink lines indicate the contribution during La Niña and El Niño years, respectively), the contribution from the NA presents a slight increase (decrease) from June of year 0 to January of year 1 for El Niño (La Niña) years with respect to the climatology. Then, there is a reverse in the signal of the NA anomalies, and the contribution from this box region towards the Amazon Basin decreases (increases) during FMAM of year 1 of an El Niño (La Niña) event. The VIMF differences (Fig. 5, right-hand column) may illustrate some aspects of the variability of the NA contribution. The positioning of the NA box coincides with the region of increased VIMF divergence observed over the equatorial Atlantic during the first months of an El Niño cycle. It may explain the higher moisture contributions from this box to the Amazon. However, it seems that the location of NA coincides with the anomalous Atlantic ITCZ displaced northwards during the austral autumn. A reduction in the moisture contribution from this box is then a plausible consequence. In comparison to the NA, the anomalies of the SA contribution present higher variability in their signal during an ENSO cycle. Some increase in the SA contribution prevails from September (year 0) to February (year 1) during La Niña events. Figure $2 b$ also indicates the change in the signal of the anomalies over the SA boxes at the end of the ENSO cycle. This means that during an El Niño (a La Niña) event, the contribution from the SA is increased (decreased) from February of year 1 onwards. Doubtlessly, as a result of the inhibition of the Atlantic ITCZ southwards during the austral autumn of an El Niño cycle, an intensified VIMF divergence (Fig. 7, right-hand column) was configured in the $\mathrm{SA}$ region, from where the moisture transport was intensified towards the Amazon.

If we consider the six flood years in the Amazon (1988/89, 1993/94, 1998/99, 2008/09, 2010/11, 2011/12) and five drought years (1979/80, 1982/83, 1997/98, 2004/05, 2009/10) identified from the previous studies of Marengo et al. $(2013 \mathrm{a}, \mathrm{b})$, the anomalous contributions from the SA and the NA boxes verified in the ENSO events are quite similar to the anomalous transports during these drought and flood episodes (figure not shown). This may be explained due to the strong similarity of the elements selected for both com-
Table 1. Correlation coefficients between the monthly time series of ONI (and AMM) and: values of 10-day $(E-P)$ backward trajectories from the Amazon Basin integrated over the NA and the SA source regions; of absolute values of 10-day $(E-P)$ forward trajectories from the Amazon Basin integrated over the LP sink area. All time series cover a 33 -year period. Values statistically significant at the $90 \%$ level according to a $t$-test are denoted $*$.

\begin{tabular}{|c|c|c|c|c|c|c|}
\hline & \multicolumn{2}{|c|}{ the NA $x$} & \multicolumn{2}{|c|}{ the SA $x$} & \multicolumn{2}{|c|}{ LP $x$} \\
\hline & ONI & AMM & ONI & AMM & ONI & AMM \\
\hline Jun & $0.36^{*}$ & -0.02 & $0.32 *$ & 0.05 & 0.05 & 0.13 \\
\hline Jul & $0.47 *$ & 0.13 & $0.37 *$ & 0.07 & 0.27 & 0.21 \\
\hline Aug & $0.55^{*}$ & 0.11 & 0.24 & 0.10 & -0.11 & -0.19 \\
\hline Sep & $0.31 *$ & 0.03 & $-0.41 *$ & -0.02 & -0.10 & -0.01 \\
\hline Oct & $0.33^{*}$ & -0.05 & -0.16 & 0.11 & $0.69^{*}$ & 0.16 \\
\hline Nov & 0.24 & 0.10 & -0.01 & -0.22 & $0.48^{*}$ & 0.19 \\
\hline Dec & 0.26 & -0.22 & 0.04 & 0.08 & $0.47^{*}$ & -0.20 \\
\hline Jan & 0.09 & -0.26 & $-0.34 *$ & 0.27 & 0.04 & 0.24 \\
\hline Feb & -0.19 & $-0.41 *$ & -0.03 & $0.38 *$ & 0.03 & -0.02 \\
\hline Mar & $-0.37 *$ & $-0.31 *$ & $0.34 *$ & $0.41 *$ & 0.18 & -0.06 \\
\hline Apr & $-0.53 *$ & $-0.69 *$ & $0.50 *$ & $0.62 *$ & $0.48^{*}$ & $0.31 *$ \\
\hline May & $-0.38 *$ & $-0.76^{*}$ & $0.46^{*}$ & $0.59^{*}$ & $0.51 *$ & $0.30 *$ \\
\hline
\end{tabular}

posites. Only one (1993/94) of the six flood years identified was associated with neutral ENSO conditions, while the other events took place during La Niña episodes. The same occurred for drought years: only one (1979/80) of the five episodes did not take place during El Niño conditions.

In the search for some interannual joint variability between ENSO and the contribution from the two sources, a correlation analysis was undertaken between the monthly time series of ONI and of $(E-P)$ integrated over each box. The correlations are indicated in Table 1 , and only those coefficients significant at the $90 \%$ level according to the $t$-test are discussed. In view of the linear relationship between the ENSO and the NA time series, the negative correlation for the months of MAM implies that during La Niña (El Niño) events the contribution from NA to the Amazon Basin increases (decreases), in accordance with Fig. 2b. The positive correlation obtained during the period from June to October might have some influence on the establishment of the transition phase of the role of the NA as a moisture source (climatologically it occurs during September). When we consider the contribution of SA, the positive ONI/SA correlation coefficients observed during MAM imply that the contribution from the SA towards the Amazon increases (decreases) during El Niño (La Niña) events, in accordance with the results shown in Fig. 2b. The negative ONI/SA correlations observed in September and January mean that the contribution from the SA increases (decreases) during La Niña (El Niño) events. A comparison of the results obtained for the two boxes reveals that the NA and the SA present opposite behaviour in terms of their joint linear variability with the ENSO, except during June and July when both indexes show positive correlation coefficients. During spring, the contribution from NA increases during El Niño events, while that 
from SA decreases during September. We do not intend to address it here, but a theme worthy of investigation in more detail in future work is the possible role of the interaction between the ENSO and the NA and SA contributions on the onset of the active phase of SAMS during austral spring (Vera et al., 2006). Furthermore, autumn is the season with the most contrasting coefficients, and this coincides with the peak of the rainy season in the Amazon Basin. While the contribution from SA increases in MAM during El Niño events, the contribution from NA decreases.

In order to demonstrate the impact of the ENSO on moisture transport from the Amazon, Fig. 6 shows the differences in the composites of the moisture sinks for El Niño and La Niña events. In the composite figures we considered only negative $(E-P)$ values (sink regions) obtained in the forward analysis from the basin. The pink (green) colours indicate regions where the moisture sinks intensified during El Niño (La Niña) events. It seems that the transport from the Amazon was enhanced towards southeastern South America (particularly the La Plata Basin) during the beginning of the El Niño phase, and this anomalous sink is displaced northwards during the cycle. The VIMF differences (Fig. 5, righthand column) reveal the predominance of intensified moisture transport towards the subtropics and enhanced moisture flux convergence over southeastern South America during an El Niño cycle. During the onset of El Niño events (from June to August in year 0), the moisture contribution increased towards the northwestern Amazon and the Pacific ITCZ (pink colour), and this last region acted again as an anomalous sink from February to April (year 1). Again, the VIMF differences suggest some moisture transport towards the Pacific ITCZ, particularly from November (year 0) onwards. This might be understood via the eastward displacement of the Walker cell, increasing precipitation over the eastern equatorial Pacific. Instead, moisture transport is enhanced towards northwestern South America and the Atlantic ITCZ during the onset of La Niña events (from June to September in year 0, green colour). From the austral spring onwards for La Niña events, the moisture transport was enhanced towards the tropical latitudes. The anomalous patterns of moisture transport from the Amazon indicated in this figure are in accordance with the precipitation anomalies observed during El Niño: precipitation displaced from the tropical region towards the La Plata Basin and drought conditions over the northern continent (Vera et al., 2006).

The variability of the contribution from the Amazon Basin towards LP during an ENSO cycle as obtained using our composite analysis is quantified in Fig. $4 \mathrm{~b}$, in which the green and pink lines indicate the contribution during La Niña and El Niño years, respectively. This figure confirms the changes in the transport towards the tropics or subtropics according to the ENSO phase, as discussed in the previous paragraph. In general, the contribution towards LP increases during El Niño episodes, particularly during July (year 0), October (year 0) - January (year 1), and March-May (year 1). The increased contribution towards LP between October (year 0) and January (year 1) for El Niño events coincides with the slight greater supply of moisture from NA towards the Amazon (Fig. 2b) observed during these years. However, the increased contribution from the Amazon towards LP during March-May (year 1) coincides with a higher supply from the SA (Fig. 2b). The results for the La Niña composite indicate a reduction in the contribution from the Amazon towards LP, particularly during October-December (year 0) and MarchMay (year 1). The linear correlation analysis applied between the time series of ONI and of absolute values of $(E-P)$ from the forward experiment integrated over LP (Table 1) shows the predominance of positive correlation coefficients, presenting higher values in October-December (year 0) and April-May (year 1). This indicates that during El Niño (La Niña) events the supply of moisture from the Amazon Basin towards LP is enhanced (reduced), in agreement with the results obtained from the composite analysis (Fig. 4b).

In a tentative summary of the main results obtained from the composites and linear correlation analyses, it seems that the moisture contribution from NA was enhanced towards the Amazon Basin during June-October (year 0) for El Niño episodes, as well as some increase in the transport from SA during June-July (year 0 ). This suggests that moisture transport towards the basin was more associated with the ENSO during the pre-monsoon period. Nevertheless, the ENSO episodes are associated more with the transport from the Amazon towards LP during the monsoon active phase (from October year 0 onwards).

\subsection{Role of the AMM in the moisture transport over the Amazon Basin}

Although almost all the drought and flood years identified by Marengo et al. (2013a, b) were associated with ENSO extreme episodes, it is interesting to note that two of them occurred during neutral ENSO conditions. This suggests an effect of other climatic modes on the variability of precipitation in the basin. When we considered the tropical Atlantic, we found that these two episodes were related to extreme AMM conditions. Moreover, three of the six flood years selected by Marengo et al. (2013a, b) occurred during AMM- episodes (1988/89, 1993/94 and 2008/09), while three of the five drought years were associated with AMM+ events $(1979 / 80,1982 / 83,2009 / 10)$. We must stress that not all the extreme AMM episodes selected were related to the drought and flood years investigated: only three of the seven $\mathrm{AMM}+(-)$ episodes were drought (flood) years. Previous studies reported some related variability of the SST anomalies over the equatorial Pacific and tropical Atlantic oceans characterised by El Niño and AMM+ conditions (and viceversa) (e.g. Chang et al., 2001; Czaja et al., 2002; Melice and Servain, 2003), in partial agreement with our results: three (two) drought (flood) years were observed during El Niño/AMM+ (La Niña/AMM-) conditions. In particular, in 
Differences in the Composites of Moisture Sink Regions (from FF Analysis): El Niño - La Niña Years
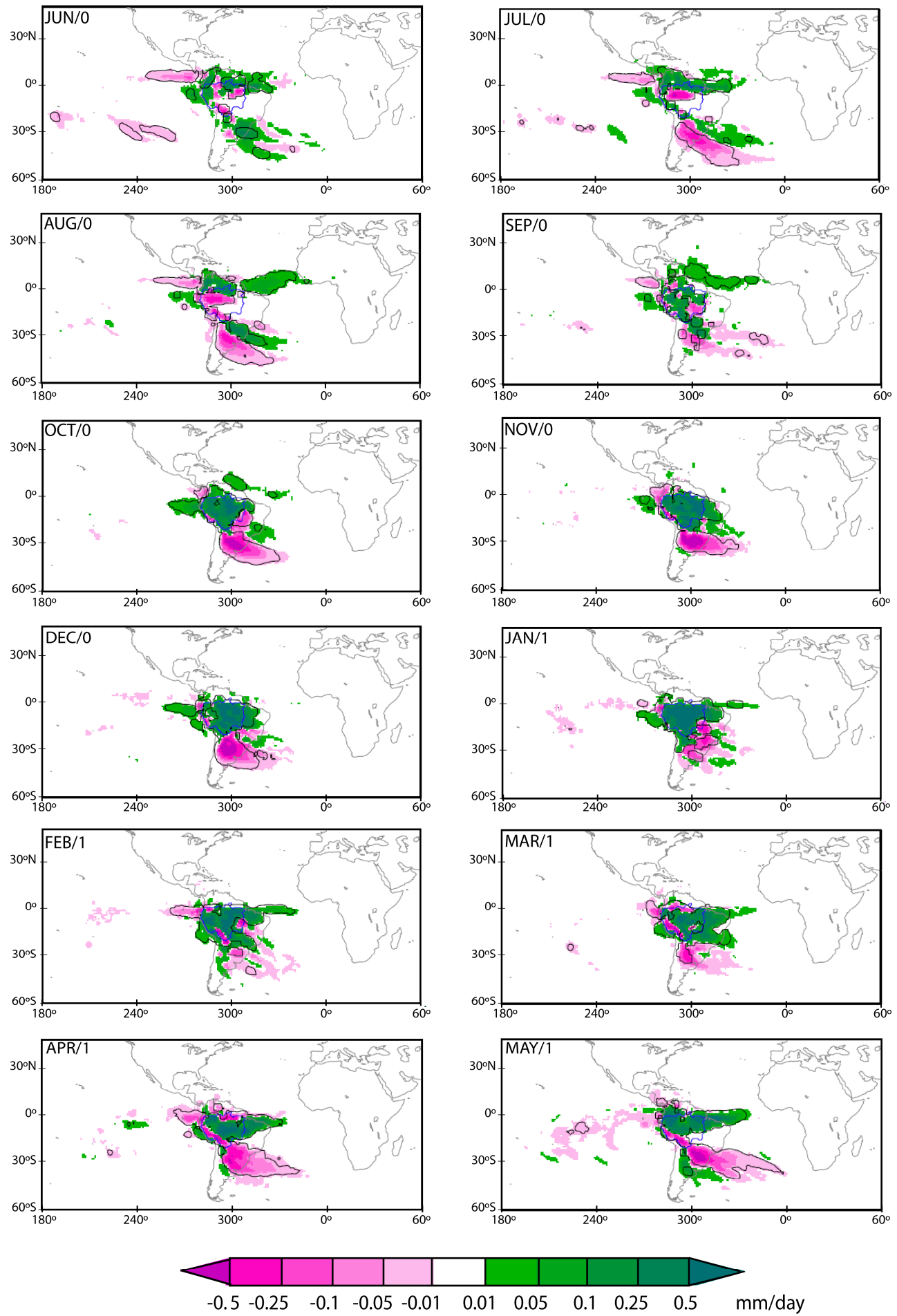

Figure 6. Differences of composites of moisture sinks of the Amazon Basin (considering only negative $E-P$ values in the composites using forward analysis) of extreme ENSO episodes. Black contour lines indicate regions where the differences are significant at the $90 \%$ level according to the bootstrap test. Pink (green) colours indicate regions where the sinks are more intense during El Niño (La Niña) years. Blue contour line indicates the basin area. 
agreement with the present results, Souza et al. (2005) also analysed the two extreme and contrasting climatic scenarios, defined as UNFAV (UNFAVorable - simultaneous manifestations of the El Niño and AMM+) and FAV (FAVorable - concomitant occurrence of the La Niña and AMM-). UNFAV (FAV) composites for unfiltered austral autumn data showed outstanding changes in both the Walker and Hadley cells in association with anomalous weakening (strengthening) in the Atlantic ITCZ that, in consequence, yields deficient (abundant) rainfall in most of the eastern Amazon and northeastern Brazil. However, it seems that anomalous Atlantic conditions accompanied by a neutral ENSO phase can also be associated with extreme precipitation years in the Amazon.

Figure 7 shows the temporal evolution of the differences in AMM+ and AMM - composites of moisture sources of the Amazon Basin over the year (left-hand columns). Again, both composite fields were established considering only positive $(E-P)$ values (source regions) obtained in the backward analysis. Pink (green) colours reveal regions where the contribution of a source intensified during AMM+ (AMM-) years. When we compare the two cases, it seems that an anomalous see-saw structure of the moisture sources prevailed during FMAM (year 1), with the South (North) Atlantic region increasing its contribution towards the Amazon during $\mathrm{AMM}+(-)$ episodes. Considering the VIMF differences for the two composites (Fig. 7, right-hand column), a cyclonic structure configured over the Northern Hemisphere suggests the weakening of the Azores High from December (year 0) onwards for AMM+ episodes. VIMF convergence was then favoured over an area covering the eastern and tropical North Atlantic, and from January (year 1) onwards a dipolar structure was configured over the tropical Atlantic, increasing convergent conditions over NA and divergence over SA. This pattern agrees with the source analysis discussed above, and suggests the displacement of the Atlantic ITCZ northwards during the AMM+ events studied. From the same figure it is possible to identify the intensification of the moisture transport from SA towards the Amazon, probably due to enhanced VIMF convergent conditions configured over the eastern equatorial Pacific and the north of the continent during the AMM+ phase. In April (year 1) of the same episodes, an anticyclonic structure was favoured over central South America, and this probably reinforced the moisture transport from SA towards the Amazon, as well as the transport from the basin towards the subtropics. Considering only the AMM- years, the results suggest changes in the structure of the anomalous moisture sources over the months of interest. While the moisture contribution prevailed from the equatorial and tropical South Atlantic regions from June to November (year 0; green colours), the anomalous source was displaced towards the North Atlantic region from December (year 0) onwards. During AMM+ years, it seems that some moisture was contributed by the basin itself from June to October (year 0). Afterwards, the anomalous source extended its domain towards northern South America, as well as to the equatorial and the tropical South Atlantic regions. A similar evolution in the enhanced VIMF divergence extending from eastern Amazon Basin towards the tropical Atlantic during the AMM+ phase agrees with the enhanced importance of these areas as moisture sources for our target area.

If we consider the variability of $(E-P)$ integrated over the NA and the SA regions during the years of extreme of AMM (Fig. 2c, green and pink lines indicate the contribution during AMM - and AMM+ events, respectively), it seems that the major changes in the contribution from the two sources compared with the climatology occur from December (year 0) onwards. Confirming the see-saw structure identified in Fig. 7, it seems that the contribution from NA increased (decreased) and that from SA decreased (increased) during AMM $-(+)$ episodes. Such a relationship tallies with the linear correlation analysis between the AMM and the NA and the SA time series shown in the Table 1.

In order to investigate possible changes in the moisture transport from the basin associated with extreme AMM years, Fig. 8 shows the differences in the positive and negative AMM phase composites of the moisture sinks in the Amazon. Here, the pink (green) colours indicate regions where moisture sinks intensify during $\mathrm{AMM}+(-)$ years. These results suggest some monthly variability in the preferred sinks. Nevertheless, it seems that moisture transport intensified towards the subtropical South America (the Amazon and northeastern Brazil) during the AMM+(-) phase, particularly from October of year 0 onwards. From June to September of year 0 the anomalous patterns were mixed, but they suggest some presence of anomalous sinks over the western (eastern) Amazon and subtropical (extratropical) South America during AMM+(-) events. Transport was also favoured towards northwestern South America and the Pacific ITCZ during the austral spring of each AMM+ episode. All these patterns may also be identified via VIMF analysis (Fig. 7, right-hand column): during the AMM+ phase, VIMF convergent conditions predominated over the subtropical South America (with some temporal variation in the spatial domain) and over the eastern equatorial Pacific and northwestern continental areas.

The variability in the anomalous contribution from the Amazon Basin towards LP during extreme AMM years is quantified in Fig. 4c, where the green and pink lines indicate the contribution during AMM- and AMM+ years, respectively. It is interesting to note that the anomalous contribution towards LP presents variability over the year: this increased (reduced) during the periods October of year 0 to January of year 1 and April-May of year 1 in AMM+(-) years. This is probably associated with the temporal variations in the location of the intensified VIMF convergent subtropical nuclei as verified in Fig. 7. The correlation analysis presented in Table 1 confirms that there is a significant linear relationship between the AMM and the contribution towards LP only during April-May (year 1). 
Differences in the Composites: (AMM+) - (AMM-) Years
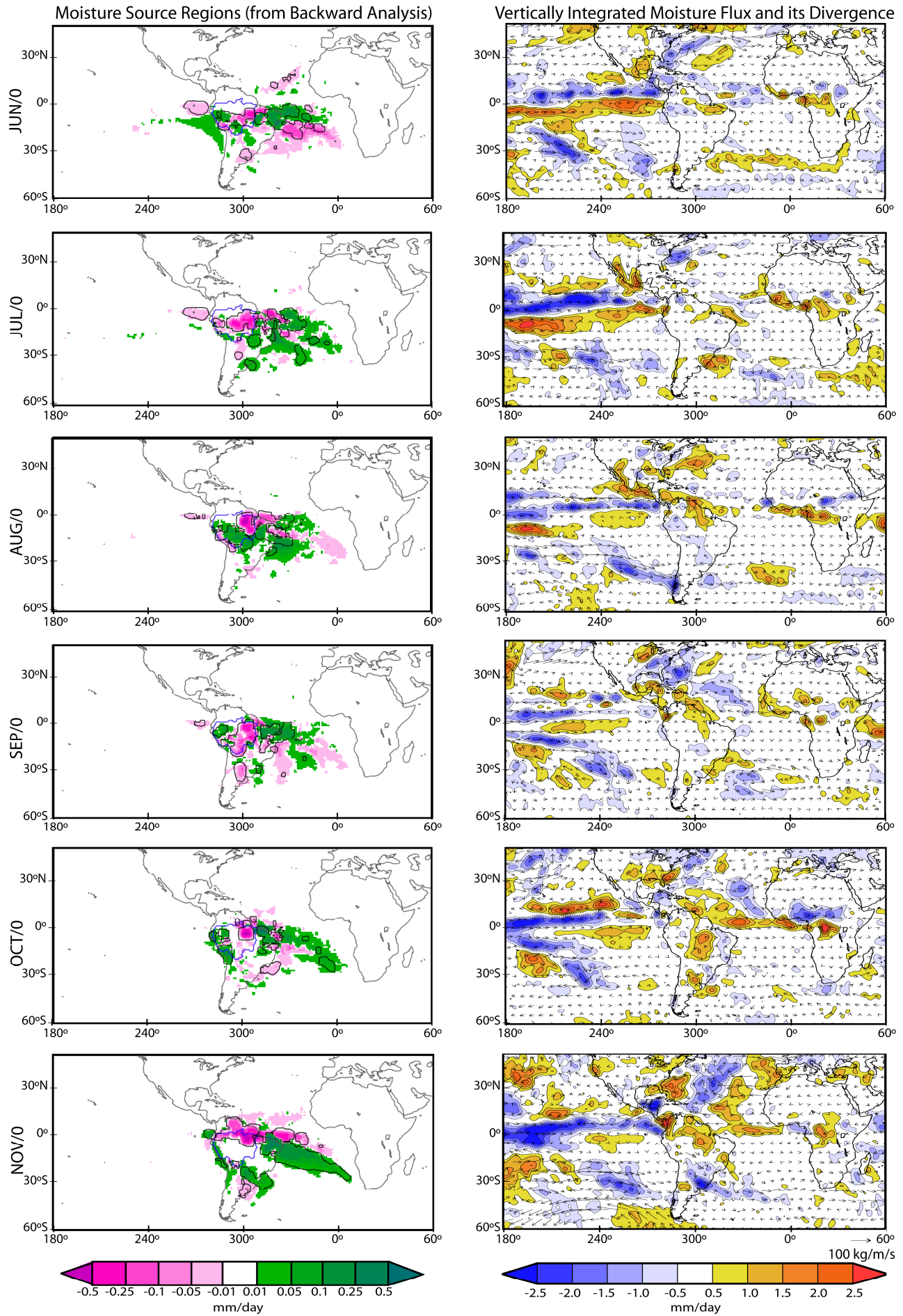

Figure 7. As Fig. 5, but for extreme AMM episodes. Pink (green) colours in the left-hand column indicate regions where the sources are more intense during $\mathrm{AMM}+(\mathrm{AMM}-)$ events. 
Differences in the Composites: (AMM+) - (AMM-) Years
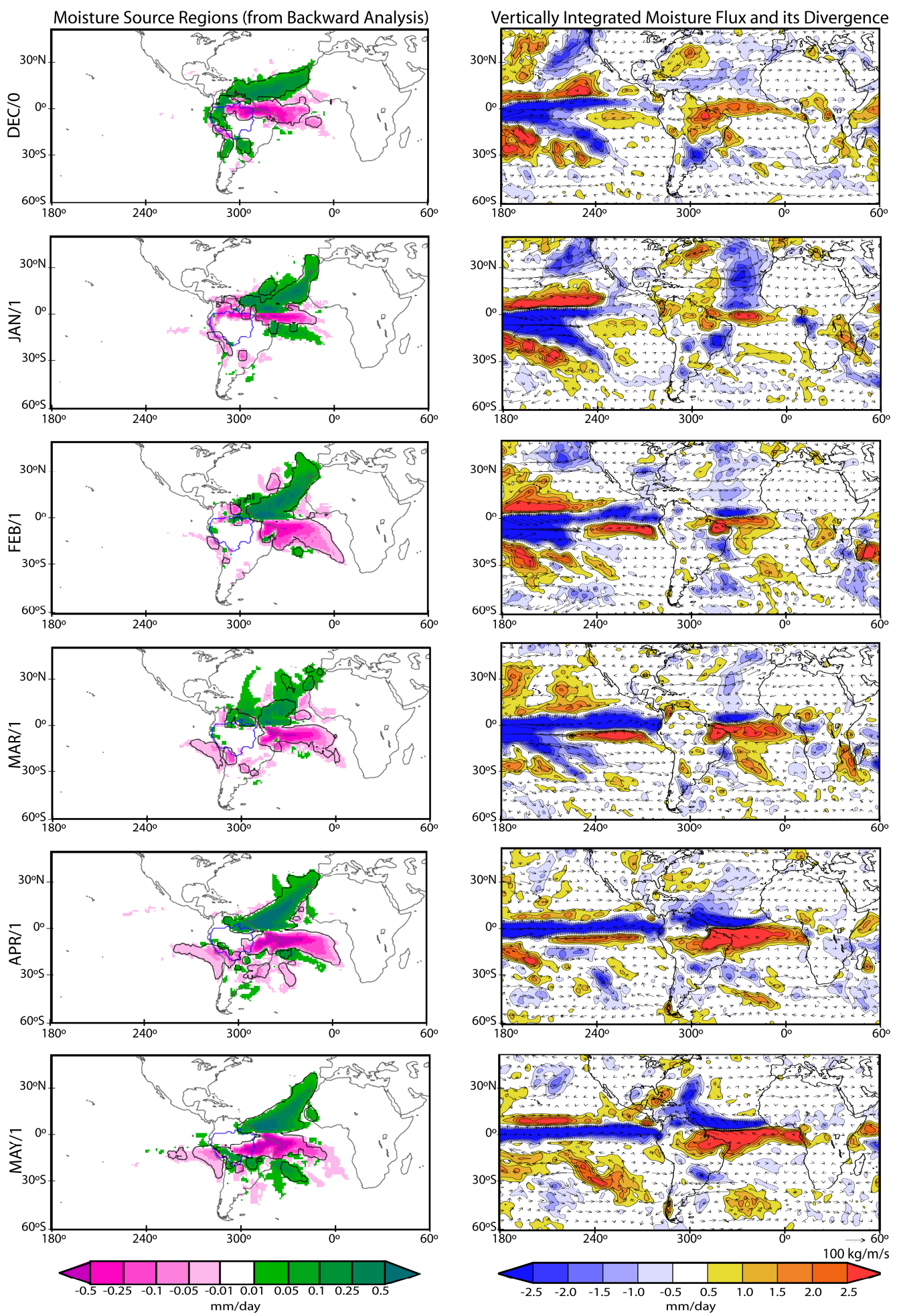

Figure 7. Continued. 
Differences in the Composites of Moisture Sink Regions (from FF Analysis): (AMM +) - (AMM-) years
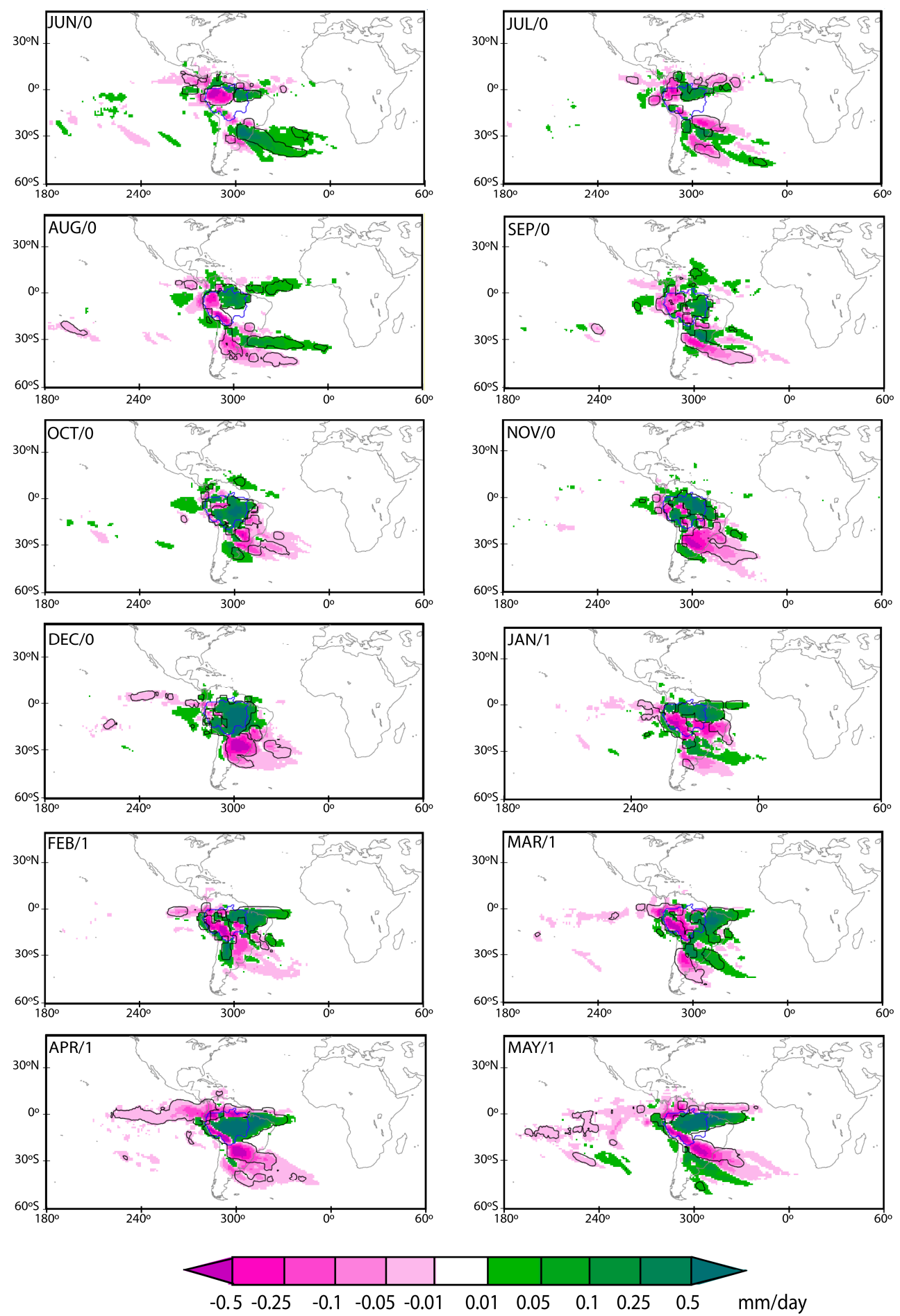

Figure 8. As Fig. 6, but for extreme AMM episodes. Pink (green) colours in the left-hand column indicate regions where the sinks are more intense during $\mathrm{AMM}+(\mathrm{AMM}-)$ events. 


\section{Conclusions}

An analysis of the moisture sources for the Amazon Basin, as well as its role as a source of humidity, was performed using a Lagrangian method of diagnosis through numerical experiments with the FLEXPART model and the ERA-Interim data set. The climatological annual cycle of the main moisture sources and sinks of the Amazon was characterised for the period June 1979 to May 2012. The large temporal domain (33-year) allowed the investigation of some aspects of the interannual variability of the moisture transport over the basin, such as the role of the anomalous SST conditions in the Pacific and the Atlantic on the Amazonian hydrological budget.

The results obtained show the role of the tropical Atlantic as a remote source of moisture for the Amazon Basin. The northern tropical Atlantic (NA) contributes mainly during the extended austral summer, and this region does not act as a moisture source for the Amazon Basin between June and September, and the transition between the sink/source role of the NA occurs in September. On the other hand, the contribution of the tropical South Atlantic (SA) occurs all year and predominates from April to November, reaching its maximum during the austral winter. Considering the Amazon Basin as a source of moisture, the main contribution from the Amazon occurs for southeastern South America throughout the year and also for southeast Brazil during the austral spring and summer months. The Orinoco Basin and the Pacific ITCZ also receive some moisture from the Amazon region, except during the austral summer.

A classification of the severe years according to the ENSO and AMM conditions suggests that the drought years identified by Marengo et al. (2013a, b) coincided with El Niño and/or AMM+ phases, and vice-versa. Concerning the role of the ENSO and AMM climatic modes on the interannual variability of the moisture transport over the Amazon, it seems that the ENSO is more associated with the interannual variability of the NA contribution during the months before the peak of the rainy season in the basin (FMAM), and El Niño events enhance the transport from this source towards the basin. During FMAM, both ENSO and AMM modes are associated with the interannual variability of the contribution from the sources, although correlation analysis suggests that the linear relationship with AMM is higher. La Niña episodes accompanied with negative AMM conditions were associated with a higher contribution from NA in these months. For the variability of the SA source, the results suggest some linear association with ENSO and particularly with AMM during FMAM, and El Niño (La Niña) episodes with $\mathrm{AMM}+(\mathrm{AMM}-)$ events were associated with enhanced (reduced) transport from SA. If we consider the transport from the basin towards LP, it seems that the ENSO has a stronger linear association, and El Niño (La Niña) episodes were associated with higher (lower) contributions.
In summary, the results from the composites and the linear correlation analyses suggest that during the peak of the rainy season (FMAM) the AMM is associated more with the interannual variations in the contribution from both the tropical Atlantic sources, while the transport from the basin towards the LP responds more to the ENSO variability. It seems that in the absence of an anomalous mechanism of moisture transport from the Amazon towards the subtropics during neutral ENSO years, the anomalies of moisture in the basin are associated with the role of the AMM in the contribution from the oceanic climatological sources. Unfortunately, the extreme drought/flood year sample is small and only two episodes were configured during neutral ENSO years, which renders our statements inconclusive. The use of dynamical climatic models to investigate the joint role of the ENSO and the AMM on the hydrological budget of the basin during these Amazon drought/flood years may address this lack of data and help us to understand the mechanisms involved in the variations in moisture transport.

Acknowledgements. Anita Drumond, Raquel Nieto and Luis Gimeno acknowledge the support from the Spanish Government and FEDER through the project TRAMO. Tercio Ambrizzi and Jose Marengo would like to acknowledge the contribution of the Rede Clima, Brazilian National Institute of Science and Technology (INCT) for Climate Change, funded by CNPq Grant Number 573797/2008-0 and FAPESP Grant Numbers 2008/57719-9, 2008/58101-9, 2008/58161-1 and Go Amazon 2013/50538-7. We acknowledge the constructive comments of the Editor Ying Fan and of the Anonymous Reviewers.

Edited by: Y. Fan

\section{References}

Angelini, I. M., Garstang, M., Davis, R. E., Hayden, B., Fitzjarrald, D. R., Legates, D., Greco, S., Macko, S., and Connors, V.: On the coupling between vegetation and the atmosphere, Theor. Appl. Climatol., 105, 243-261, doi:10.1007/s00704-010-0377-5, 2011

Arraut, J. M. and Satyamurty, P.: Precipitation and Water Vapor Transport in the Southern Hemisphere with Emphasis on the South American Region, J. Appl. Meteor. Climatol., 48, 19021912, doi:10.1175/2009JAMC2030.1, 2009.

Arraut, J. M., Nobre, C., Barbosa, H. M. J., Obregon, G., and Marengo, J.: Aerial Rivers and Lakes: Looking at Large-Scale Moisture Transport and Its Relation to Amazonia and to Subtropical Rainfall in South America, J. Climate, 25, 543-556, doi:10.1175/2011JCLI4189.1, 2012.

Bagley, J. E., Desai, A. R., Harding, K. J., Snyder, P. K., and Foley, J. A.: Drought and deforestation: Has land cover change influenced recent precipitation extremes in the Amazon?, J. Climate, 27, 345-361, doi:10.1175/JCLI-D-12-00369.1, 2014.

Bengtsson, L., Hagemann, S., and Hodges, K. I.: Can climate trends be calculated from reanalysis data?, J. Geophys. Res., 109, D11111, doi:10.1029/2004JD004536, 2004. 
Bosilovich, M. G. and Chern, J.-D.: Simulation of water sources and precipitation recycling for the MacKenzie, Mississippi, and Amazon river basins, J. Hydrometeorol., 7, 312-329, 2006

Brubaker, K. L., Entekhabi, D., and Eagleson, P. S.: Estimation of continental precipitation recycling, J. Climate, 6, 1077-1089, 1993.

Carvalho, L. M. V., Silva, A. E., Jones, C., Liebmann, B., Silva Dias, P. L., and Rocha, H. R.: Moisture transport and intraseasonal variability in the South America monsoon system, Clim. Dynam., 36, 1865-1880, 2011.

Chang, P., Ji, L., and Saravanan, R.: A hybrid coupled model study of tropical Atlantic variability, J. Climate, 14, 361-390, 2001.

Coe, M., Costa, M. H., Botta, A., and Birkett, C.: Long term simulations of discharge and floods in the Amazon river, J. Geophys. Res., 107, 11-1-11-17, 2002.

Costa, M. H. and Foley, J. A.: Trends in the hydrologic cycle of the Amazon basin, J. Geophys. Res., 104, 14189-14198, 1999.

Czaja, A., van der Vaart, P., and Marshall, J.: A diagnostic study of the role of remote forcing in tropical Atlantic variability, J. Climate, 15, 3280-3290, 2002.

Dee, D. P., Uppala, S. M., Simmons, A. J., Berrisford, P., Poli, P., Kobayashi, S., Andrae, U., Balmaseda, M. A., Balsamo, G., Bauer, P., Bechtold, P., Beljaars, A. C. M., van de Berg, L., Bidlot, J., Bormann, N., Delsol, C., Dragani, R., Fuentes, M., Geer, A. J., Haimberger, L., Healy, S. B., Hersbach, H., Hólm, E. V., Isaksen, L., Kållberg, P., Köhler, M., Matricardi, M., McNally, A. P., Monge-Sanz, B. M., Morcrette, J.-J., Park, B.-K., Peubey, C., de Rosnay, P., Tavolato, C., Thépaut, J.-N. and Vitart, F.: The ERA Interim reanalysis: Configuration and performance of the data assimilation system, Q. J. Roy. Meteorol. Soc., 137, 553597, doi:10.1002/qj.828, 2011.

Dirmeyer, P. A. and Brubaker, K. L.: Characterization of the global hydrologic cycle from a back-trajectory analysis of atmospheric water vapor, J. Hydrometeorol., 8, 20-37, 2007.

Dirmeyer, P. A., Schlosser, C. A., and Brubaker, K. L.: Precipitation, Recycling, and Land Memory: An Integrated Analysis, J. Hydrometeor., 10, 278-288, doi:10.1175/2008JHM1016.1, 2009.

Drumond, A., Nieto, R., Gimeno, L., and Ambrizzi, T.: A lagrangian identification of major sources of moisture over Central Brazil and La Plata Basin, J. Geophys. Res., 113, D14128, doi:10.1029/2007JD009547, 2008.

Drumond, A., Nieto, R., Trigo, R., Ambrizzi, T., Souza, E., and Gimeno, L.: A Lagrangian Identification of the Main Sources of Moisture Affecting Northeastern Brazil during Its Pre-Rainy and Rainy Seasons, PLoS ONE, 5, e11205, doi:10.1371/journal.pone.0011205, 2010.

Drumond, A., Nieto, R., and Gimeno, L.: On the contribution of the Tropical Western Hemisphere Warm Pool source of moisture to the Northern Hemisphere precipitation through a Lagrangian approach, J. Geophys. Res., 116, D00Q04, doi:10.1029/2010JD015397, 2011.

Eltahir, E. A. B. and Bras, R. L.: Precipitation recycling in the Amazon Basin, Q. J. Roy. Meteorol. Soc., 120, 861-880, 1994.

Foley, J. A., Botta, A., Coe, M. T., and Costa, M. H.: El NiñoSouthern Oscillation and the climate, ecosystems and rivers of Amazonia, Global Biogeochem. Cy., 16, 1132-1144, 2002.

Folland, C. and Parker, P. D.: Sahel rainfall and worldwide surface temperatures: 1901-1985, Nature, 320, 602-606, 1986.
Gat, J. R. and Matsui, E.: Atmospheric water balance in the Amazon basin: An isotopic evapotranspiration model, J. Geophys. Res., 96, 13179-13188, doi:10.1029/91JD00054, 1991.

Gimeno, L., Stohl, A., Trigo, R. M., Dominguez, F., Yoshimura, K., Yu, L., Drumond, A., Durán-Quesada, A. M., and Nieto, R.: Oceanic and Terrestrial Sources of Continental Precipitation, Rev. Geophys., 50, RG4003, doi:10.1029/2012RG000389, 2012.

Gimeno, L., Nieto, R., Drumond, A., Castillo, R., and Trigo, R.: Influence of the intensification of the major oceanic moisture sources on continental precipitation, Geophys. Res. Lett., 40, 18, doi:10.1002/grl.50338, 2013.

Grimm, A. M. and Ambrizzi, T.: Teleconnections into South America from the Tropics and Extratropics on Interannual and Intraseasonal Timescales, in: Françoise Vimeux, Florence Sylvestre, Myriam Khodri. (Org.), Past Climate Variability in South America and Surrounding Regions, Netherlands, Springer Netherlands, Vol. 14, 159-191, 2009.

Keys, P. W., van der Ent, R. J., Gordon, L. J., Hoff, H., Nikoli, R., and Savenije, H. H. G.: Analyzing precipitationsheds to understand the vulnerability of rainfall dependent regions, Biogeosciences, 9, 733-746, doi:10.5194/bg-9-733-2012, 2012.

Knippertz, P., Wernli, H., and Glaser, G.: A global climatology of tropical moisture, J. Climate, 26, 3031-3045, doi:10.1175/JCLID-12-00401.1, 2013.

Kousky, V. E., Kagano, M. T., and Cavalcanti, I. F. A.: A review of the Southern Oscillation: oceanic-atmospheric circulation changes and related rainfall anomalies, Tellus, 36A, 490504, 1984.

Lewis, S. L., Brando, P. M., Phillips, O. L., van der Heijden, G. M. F., and Nepstad, D.: The 2010 Amazon Drought, Science, 331, 554, doi:10.1126/science.1200807, 2011.

Liebmann, B. and Marengo, J. A.: Interannual Variability of the Rainy Season and Rainfall in the Brazilian Amazon Basin, J. Climate, 14, 4308-4318, doi:10.1175/15200442(2001)014<4308:IVOTRS>2.0.CO;2, 2001.

Makarieva, A. M., Gorshkov, V. G., Sheil, D., Nobre, A. D., and Li, B.-L.: Where do winds come from? A new theory on how water vapor condensation influences atmospheric pressure and dynamics, Atmos. Chem. Phys., 13, 1039-1056, doi:10.5194/acp-131039-2013, 2013.

Marengo, J. A.: The characteristics and variability of the atmospheric water balance in the Amazon basin: Spatial and temporal variability, Clim. Dynam., 24, 11-22, 2005.

Marengo, J. A.: On the hydrological cycle of the Amazon Basin: a historical review and current state-of-the-art, Revista Brasileira de Meteorologia, 21, 1-19, 2006.

Marengo, J. and Nobre, C.: Clima da regiao Amazonica, in: Tempo e clima no Brasil, edited by: Cavalcanti, I. F. A ., Oficina de Textos, Sao Paulo, Brazil, 197-212, 2009 (in Portuguese).

Marengo, J. A., Liebmann, B., Kousky, V., Filizola, N., and Wainer, I.: Onset and end of the rainy season in the Brazilian Amazon basin, J. Climate, 14, 833-852, 2001.

Marengo, J. A., Nobre, C. A., Tomasella, J., Oyama, M. D., Oliveira, G. S., Oliveira, R., Camargo, H., and Alves, L. M.: The dought of Amazonia in 2005, J. Climate, 21, 495-516, 2008.

Marengo, J. A., Borma, L. S., Rodriguez, D. A., Pinho, P., Soares, W. R., and Alves, L. M.: Recent Extremes of Drought and Flooding in Amazonia: vulnerabilities and human adaptation, Am. J. Clim. Change, 2, 87-96, doi:10.4236/ajcc.2013.22009, 2013a. 
Marengo, J. A., Alves, L. M., Soares, W. R., Rodriguez, D. A., Camargo, H., Riveros, M. P., and Pabló, A. D.: Two Contrasting Severe Seasonal Extremes in Tropical South America in 2012: Flood in Amazonia and Drought in Northeast Brazil, J. Climate, 26, 9137-9154, doi:10.1175/JCLI-D-12-00642.1, 2013b.

Melice, J. L. and Servain, J.: The tropical Atlantic meridional SST gradient index and its relationships with SOI, NAO and the Southern Ocean, Clim. Dynam., 20, 447-464, 2003.

Molion, L. C. B.: A climatonomic study of the energy and moisture fluxes of the Amazon basin with considerations of deforestation effects, Ph. D. thesis, University of Wisconsin, Madison, 1975.

Moura, A. D. and Shukla, J.: On the dynamics of droughts in northeast Brazil: observations, theory and numerical experiments with a general circulation model, J. Atoms. Sci., 38, 2653-2675, 1981.

Nieto, R., Gallego, D., Trigo, R. M., Ribera, P., and Gimeno, L.: Dynamic identification of moisture sources in the Orinoco basin in equatorial South America, Hydrol. Sci. J., 53, 602-617, 2008.

Nóbrega, R. S., Cavalcanti, E. P., and Souza, E. P.: Reciclagem de vapor d'água sobre a América do Sul utilizando reanálises do NCEP-NCAR, Revista Brasileira de Meteorologia, 20, 253-262, 2005.

Numaguti, A.: Origin and recycling processes of precipitating water over the Eurasian continent: Experiments using an atmospheric general circulation model, J. Geophys. Res., 104, 1957-1972, 1999.

Rayner, N. A., Parker, D. E., Horton, E. B., Folland, C. K., Alexander, L. V., Rowell, D. P., Kent, E. C., and Kaplan, A.: Global analyses of sea surface temperature, sea ice, and night marine air temperature since the late nineteenth century, J. Geophys. Res., 108, 4407, doi:10.1029/2002JD002670, 2003.

Richey, J., Nobre, C. A., and Deser, C.: Amazon river discharge and climate variability: 1903 to 1985, Science, 246, 101-103, 1989.

Roads, J., Kanamitsu, M., and Stewart, R.: Water and energy budgets in the NCEP-DOE reanalyses, J. Hydrometeor., 3, 227-248, 2002.

Ropelewski, C. F. and Halpert, M. S.: Global and Regional Scale Precipitation Patterns Associated with the El Niño/Southern Oscillation, Mon. Weather Rev., 115, 1606-1626, 1987.

Salati, E.: The Forest and the Hydrological Cycle, edited by: Gash, J. H., Nobre, C. A., Roberts, J. M., and Victoria, R. L., Amazonian deforestation and climate, John Wiley and Sons, Chichester, UK, 273-296, 1987.

Satyamurty, P., da Costa, C. P. W., and Manzi, A. O.: Moisture source for the amazon Basin: a study of contrasting years, Theor. Appl. Climatol., 111, 195-209, doi:10.1007/s00704-012-0637-7, 2013a.

Satyamurty, P., da Costa, C. P. W., Manzi, A. O., and Candido, L. A.: A quick look at the 2012 record flood in the Amazon Basin, Geophys. Res. Lett., 40, 1396-1401, doi:10.1002/grl.50245, 2013 b.

Servain, J.: Simple climatic indices for the tropical Atlantic Ocean and some applications, J. Geophys. Res., 96, 15137-15146, 1991.

Silva, A. E.: Variabilidade da Circulação e Transporte de Umidade no Regime de Monção da América do Sul., 2009, 137 f., Tese (Doutorado) - Instituto de Astronomia, Geofísica e Ciências Atmosféricas, Universidade de São Paulo, São Paulo, 2009.

Smith, T. M., Reynolds, R. W., Peterson, T. C., and Lawrimore, J.: Improvements to NOAA's Historical Merged Land-Ocean Sur- face Temperature Analysis (1880-2006), J. Climate, 21, 22832296, 2008.

Souza, E. B., Kayano, M. T., and Ambrizzi, T.: Intraseasonal and submonthly variability within autumn rainy regime over the Eastern Amazon/Northeast Brazil and associated atmospheric mechanisms, Theor. Appl. Climatol., Austria, 81, 177-192, 2005.

Spracklen, D. V., Arnold, S. R., and Taylor, C. M.: Observations of increased tropical rainfall preceded by air passage over forests, Nature, 489, 282-285, doi:10.1038/nature11390, 2012.

Sternberg, H. R.: Aggravation of floods in the Amazon River as a consequence of deforestation?, Geograf. Annal., 69A, 201-219, 1987.

Stohl, A. and James, P.: A Lagrangian analysis of the atmospheric branch of the global water cycle. Part 1: Method description, validation, and demonstration for the August 2002 flooding in central Europe, J. Hydrometeor., 5, 656-678, 2004.

Stohl, A. and James, P.: A Lagrangian analysis of the atmospheric branch of the global water cycle: 2. Earth's river catchments, ocean basins, and moisture transports between them, J. Hydrometeorol., 6, 961-984, 2005.

Trenberth, K. E.: The Definition of El Niño, B. Am. Meteorol. Soc., 78, 2771-2777, 1997.

Trenberth, K. E.: Atmospheric Moisture Recycling: Role of Advection and Local Evaporation, J. Climate, 12, 1368-1381, 1999.

Uvo, C. R. B., Repelli, C. A., Zebiak, S., and Kushnir, Y.: The relationship between tropical Pacific and Atlantic SST and Northeast Brazil monthly precipitation, J. Climate, 11, 551-562, 1998.

van der Ent, R. J., Savenije, H. H. G., Schaefli, B., and Steele-Dunne, S. C.: Origin and fate of atmospheric moisture over continents, Water Resour. Res., 46, W09525, doi:10.1029/2010WR009127, 2010.

van der Ent, R. J. and Savenije, H. H. G.: Oceanic sources of continental precipitation and the correlation with sea surface temperature, Water Resour. Res., 49, 3993-4004, doi:10.1002/wrcr.20296, 2013.

Vera, C., Higgins, W., Amador, J. , Ambrizzi, T., Garreaud, R., Gochis, D., Gutzler, D., Lettenmaier, D., Marengo, J., Mechoso, C. R., Nogues-Paegle, J., Silva Dias, P. L., and Zhang, C.: Toward a unified view of the American monsoon systems, J. Climate, 19, 4977-5000, doi:10.1175/JCLI3896.1, 2006.

Wei, J., Dirmeyer, P. A., Bosilovich, M. G., and Wu, R.: Water vapor sources for Yangtze River Valley rainfall: Climatology, variability, and implications for rainfall forecasting, J. Geophys. Res., 117, D05126, doi:10.1029/2011JD016902, 2012.

Williams, E., Dall'antonia, A., Dall'antonia, V., de Almeida, J. M., Suarez, F., Liebmann, B., and Malhado, A. C. M.: The drought of the century in the Amazon basin: An analysis of the regional variation of rainfall in South America in 1926, Acta Amazonica, 35, 231-238, 2005.

Yoon, J.-H. and Zeng, N.: An Atlantic influence on Amazon rainfall, Clim. Dynam., 34, 249-264, doi:10.1007/s00382-009-05516, 2010

Yu, L., Jin, X., and Weller, R. A.: Multidecade Global Flux Datasets from the Objectively Analyzed Air-sea Fluxes (OAFlux) Project: Latent and sensible heat fluxes, ocean evaporation, and related surface meteorological variables, Woods Hole Oceanographic Institution, OAFlux Project Technical Report, OA-2008- 01, 64 pp., Woods Hole, Massachusetts, 2008. 